\title{
Chemistry of Bridging Ketene from Facile Carbonylation of a Ditungsten Methylene Complex with No Metal-Metal Bond
}

\author{
Yu-Lee Yang, Luxti J un-J ieh Wang, Ying-Chih Lin,* Shou-Ling Huang, \\ Ming-Chou Chen, Gene-Hsiang Lee, and Yu Wang \\ Department of Chemistry, National Taiwan University, Taipei, Taiwan 10764, \\ Republic of China
}

Received November 26, $1996^{\otimes}$

\begin{abstract}
The reaction of $\mathrm{Cp}(\mathrm{CO})_{3} \mathrm{~W}^{-}\left(\mathrm{Cp}=\eta^{5}-\mathrm{C}_{5} \mathrm{H}_{5}\right)$ with $\mathrm{CH}_{2} \mathrm{l}_{2}$ in $\mathrm{CH}_{3} \mathrm{CN}$ at $-20{ }^{\circ} \mathrm{C}$ gives the dinuclear acetylide complex $\mathrm{Cp}_{2}(\mathrm{CO})_{6} \mathrm{~W}_{2}(\mu-\mathrm{C} \equiv \mathrm{C})(\mathbf{2})$. When the same reaction is carried out in methanol at $-20{ }^{\circ} \mathrm{C}$, a dinuclear ketene complex, $\mathrm{Cp}_{2}(\mathrm{CO})_{5} \mathrm{~W}_{2}\left(\mu, \eta^{1}, \eta^{2}-\mathrm{CH}_{2} \mathrm{CO}\right)(5)$, is isolated. The oxygen atom of the ketene unit in $\mathbf{5}$ is weakly coordinated to one of the tungsten metal centers. Upon dissolution in $\mathrm{CH}_{3} \mathrm{CN}$ at room temperature, complex $\mathbf{5}$ transforms to 2. A bridging methylene complex, $\mathrm{Cp}_{2}(\mathrm{CO})_{4}\left[\mathrm{P}(\mathrm{OMe})_{3}\right]_{2} \mathrm{~W}_{2}\left(\mu-\mathrm{CH}_{2}\right)(\mathbf{4 a})$, has been isolated, and its facile carbonylation gives a different ketene complex, $\mathrm{Cp}_{2}(\mathrm{CO})_{2}\left[\mathrm{P}(\mathrm{OMe})_{3}\right]_{2} \mathrm{~W}_{2}\left(\mu, \eta^{1}, \eta^{1-}\right.$ $\left.\mathrm{CH}_{2} \mathrm{CO}\right)(\mu-\mathrm{CO})(6 \mathrm{a})$, in $\mathrm{CH}_{3} \mathrm{CN}$. Treatment of 5 with $\mathrm{CO}$ affords $\mathrm{Cp}_{2}(\mathrm{CO})_{6} \mathrm{~W}_{2}\left(\mu-\mathrm{CH}_{2} \mathrm{CO}\right)(\mathbf{8})$, which, upon reacting with $\mathrm{H}_{2} \mathrm{O}, \mathrm{ROH}\left(\mathrm{R}=\mathrm{Me}, \mathrm{Et}, \mathrm{PhCH}_{2}\right)$, and $\mathrm{i}-\mathrm{PrNH}_{2}$, generates mononuclear complexes $\mathrm{Cp}(\mathrm{CO})_{3} \mathrm{WCH}_{2} \mathrm{COOH}(\mathbf{9}), \mathrm{Cp}(\mathrm{CO})_{3} \mathrm{WCH}_{2} \mathrm{COOR}(\mathbf{1 2 a}-\mathbf{c})$, and $\mathrm{Cp}(\mathrm{CO})_{3} \mathrm{WCH}_{2} \mathrm{CONH}$ (i-Pr) (14), respectively. The more stable $\mathrm{Cp}^{\prime}\left(\mathrm{Cp}^{\prime}=\mathrm{C}_{5} \mathrm{H}_{4} \mathrm{Me}\right)$ analogues $\mathbf{2}^{\prime}, \mathbf{5}^{\prime}$, and $\mathbf{8}$ are also prepared. An experiment using a mixture of $\mathbf{5}$ and $\mathbf{5}^{\prime}$ to afford only $\mathbf{2}$ and $\mathbf{2}$ without the crossover product shows that intermolecular coupling is not involved in this transformation. The reaction of 5 with $\mathrm{PR}_{3}(\mathrm{R}=\mathrm{OMe}, \mathrm{Et}, \mathrm{Ph})$ yields only the trans product $\mathrm{Cp}_{2}(\mathrm{CO})_{5}\left(\mathrm{PR}_{3}\right) \mathrm{W}_{2}\left(\mu-\mathrm{CH}_{2} \mathrm{CO}\right)(\mathbf{1 0 a}-\mathbf{c})$. But the reaction of 5 with $\mathrm{t}-\mathrm{BuN} \mathrm{C}$ gives both the trans and cis products of the ketene complex $\mathrm{Cp}_{2}(\mathrm{CO})_{5}(\mathrm{t}-\mathrm{BuNC}) \mathrm{W}_{2}\left(\mu-\mathrm{CH}_{2} \mathrm{CO}\right)$ (11). Complexes 2', 5', 8', and $\mathbf{1 1}$ have been characterized by single-crystal X-ray diffraction analysis.
\end{abstract}

\section{Introduction}

Even though organic ketenes and their synthetic applications have been recognized for nearly a century, ${ }^{1}$ only recently have metal-complexed ketenes been prepared. A number of routes, including the coupling of alkylidene and carbonyl moieties, ${ }^{2}$ addition of free ketene to unsaturated metal systems, ${ }^{3}$ and deprotonation of metal acyls, ${ }^{4}$ are known for preparation of the metal-complexed ketenes. Heterobimetallic ketene complexes have been prepared from the acylation of metal anion, $\mathrm{ML}_{n}{ }^{-}$, by $\mathrm{FpCH}_{2} \mathrm{COCl}\left(\mathrm{Fp}=\mathrm{CpFe}(\mathrm{CO})_{2}\right){ }^{5}$ Attempts have been made to obtain the ketene moiety by carbonylation of a dimetallacyclopropane. However, owing to the extraordinary stability of such a threemembered-ring skel eton, the well-known $\mu$-methylene

\footnotetext{
${ }^{\otimes}$ Abstract published in Advance ACS Abstracts, March 15, 1997. (1) Brady, W. T. In The Chemistry of Ketenes, Allenes, and Related Compounds; Patai, S., Ed.; Wiley: New York, 1980; Chapter 8.

(2) (a) Herrmann, W. A.; Plank, J. Angew. Chem., Int. Ed. Engl. 1978, 17, 525. (b) Bodner, T. W.; Cutler, A. R. J . Am. Chem. Soc. 1983, 105, 5926. (c) Barger, P. T.; Santarsiero, B. D.; Armantrout, J .; Bercaw, J. E. J. Am. Chem. Soc. 1984, 106, 5178. (d) Curtis, M. D.; Messerle, L.; D'Errico, J .J .; Solis, H. E.; Barcelo, I. D.; Butler, W. M. J . Am. Chem. Soc. 1987, 109, 3603. (e) Geoffroy, G. L.; Bassner, S. L. Adv. Organomet. Chem. 1988, 28, 1.

(3) (a) Fermin, M. C.; Hneihen, A. S.; Maas, J. J .; Bruno, J. W. Organometallics 1993, 12, 1845. (b) Fermin, M. C.; Bruno, J. W. J. Am. Chem. Soc. 1993, 115, 7511.

(4) (a) Straus, D. A.; Grubbs, R. H. J . Am. Chem. Soc. 1982, 104 5499. (b) Moore, E. J .; Straus, D. A.; Armantrout, J .; Santarsiero, B. D.; Grubbs, R. H.; Bercaw, J. E. J . Am. Chem. Soc. 1983, 105, 2068. (c) Rusik, C. A.; Tonker, T. L.; Templeton, J . L. J . Am. Chem. Soc. 1986, 108, 4652. (d) Rusik, C. A.; Collins, M. A.; Gamble, A. S.; Tonker, T. L.; Templeton, J. L. J. Am. Chem. Soc. 1989, 111, 2550.
}

(5) Akita, M.; Kondoh, A.; Moro-oka, Y. J . Chem. Soc., Chem. Commun. 1986, 1296. complexes either with a metal-metal bond 6 or with some other supplementary bridging ligand are not commonly carbonylated into $\mu$-ketene. In contrast, the facile carbonylation of the dinuclear ruthenium $\mu$ methylene complex with no metal-metal bond leading to the bridging ketene was first recognized in 1983.7 Thereafter, other ketene complexes derived from CO insertion of compounds of this type have also been reported. ${ }^{8}$ It is now accepted that, relative to dimetallacyclopropane, the $\mu$-methylene group with no metalmetal bond displays higher reactivity especially through $\mathrm{CO}$ insertion to result in $\mathrm{C}-\mathrm{C}$ bond formation. From the X-ray data of the first $\mu$-methylene complex with no metal-metal bond, the $\mathrm{Ru}-\mathrm{C}-\mathrm{Ru}$ bond angle of $123(3)^{\circ}$ is observed. ${ }^{7 a}$ This feature might imitate the structure of a bridging methylene group at the kink site of a metallic surface while the dimetallacyclopropane might model that at the smooth surface. ${ }^{9}$ The higher reactivity of the $\mu$-methylene complex with no metal-

(6) (a) Herrmann, W. A. Adv. Organomet. Chem. 1982, 20, 159. (b) Herrmann, W. A. Angew. Chem., Int. Ed. Engl. 1982, 21, 117. (c) Puddephatt, R. J . Comments I norg. Chem. 1982, 2, 69a. (d) Puddephatt, R. J . Polyhedron 1988, 7, 767. (e) Saez, I. M.; Andrews, D. G.; Maitlis, P. M. Polyhedron 1988, 7, 827. (f) Knox, S. A. R. J . Organomet. Chem. 1990, 400, 255.

(7) (a) Lin, Y. C.; Calabrese, J . C.; Wreford, S. S. J . Am. Chem. Soc 1983, 105, 1679. (b) Chen, M. C.; Tsai, Y. J .; Chen, C. T.; Lin, Y. C.; Tseng, T. W.; Lee, G. H.; Wang, Y. Organometallics 1991, 10, 378.

(8) (a) Morrison, E. D.; Steinmetz, G. R.; Geoffroy, G. L.; Fultz, W. C.; Rheingold, A. L. J . Am. Chem. Soc. 1984, 106, 4783. (b) Ho, S. C. H.; Straus, D. A.; Armantrout, J .; Schaefer, W. P.; Grubbs, R. H. J. Am. Chem. Soc. 1984, 106, 2210. (c) Morrison, E. D.; Geoffroy, G. L. J. Am. Chem. Soc. 1985, 107, 3541. (d) Holmgren, J. S.; Shapley, J. R.; Wilson, S. R.; Pennington, W. T. J . Am. Chem. Soc. 1986, 108, 508. 


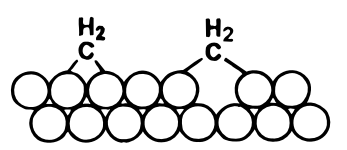

metal bond is thus a manifestation of the reactivity of the same group attached to that kink site on an irregular surface. On the basis of this belief, we set out to study a similar organometallic system using tungsten metal. In this paper we report the chemistry of various dinuclear ketene complexes derived from facile carbonylation of a methylene complex of tungsten. Part of the results has appeared in our preliminary communication. ${ }^{7 b}$

\section{Results and Discussion}

Reaction of $\mathrm{CH}_{2} \mathrm{I}_{2}$ with Tungsten Carbonylate Anion. At $-20{ }^{\circ} \mathrm{C}$ the reaction of $\mathrm{Cp}(\mathrm{CO})_{3} \mathrm{~W}^{-}(\mathbf{1})$ with 0.5 equiv of $\mathrm{CH}_{2} \mathrm{I}_{2}$ in $\mathrm{CH}_{3} \mathrm{CN}$ in 3 days affords the ditungsten acetylide complex $\mathrm{Cp}_{2}(\mathrm{CO})_{6} \mathrm{~W}_{2}(u-\mathrm{C} \equiv \mathrm{C})(\mathbf{2})$ as a dark red crystalline product. The yield of $\mathbf{2}$ is generally ca. $25 \%$ if the reaction is carried out on a $5 \mathrm{~g}$ scale and has been optimized to $31 \%$ (see Experimental Section) when the reaction is carried out on a smaller scale. Complexes $\mathrm{Cp}(\mathrm{CO})_{3} \mathrm{WMe}$ and $\mathrm{Cp}(\mathrm{CO})_{3} \mathrm{WI}$, with $35 \%$ and $38 \%$ yields, respectively, are the two major side products of this reaction. Complex $\mathbf{2}$ is soluble in polar organic solvents and is air stable in the solid state at room temperature. Some interesting physical properties are observed for 2; for example, analytically pure solid compound displays either a yellow (amorphous powder) or dark red col or (crystal line) in the solid state, but the solution always displays a yellow color. The analogous complex $\mathrm{Cp}_{2}^{\prime}(\mathrm{CO})_{6} \mathrm{~W}_{2}(\mu-\mathrm{C} \equiv \mathrm{C})\left(\mathbf{2}^{\prime}, \mathrm{Cp}^{\prime}=\eta^{5}\right.$ $\mathrm{C}_{5} \mathrm{H}_{4} \mathrm{Me}$ ) could be similarly prepared in $30 \%$ yield. Relative amounts of the reactants and solvent used in the reaction change the product. If carried out in THF with excess $\mathrm{CH}_{2} \mathrm{I}_{2}$, the reaction gives $\mathrm{Cp}(\mathrm{CO})_{3} \mathrm{WCH}_{2} \mathrm{I}$ (3) as the major product. In the ${ }^{13} \mathrm{C}$ NMR spectrum of 3 the resonance at $\delta-35.8$ with $\mathrm{J} w-\mathrm{C}=49.3 \mathrm{~Hz}$ is assigned to the methylene group. Even though $\mathbf{3}$ can be used for the synthesis of $\mathbf{2}$ by treatment with $\mathbf{1}$, the yield is much lower $(<10 \%)$.

Since there is only a singlet resonance in the ${ }^{1} \mathrm{H} N \mathrm{NR}$ spectrum of 2, more data are required to define the structure. The definitive characterization of $\mathbf{2}^{\prime}$ came from a single-crystal X-ray diffraction analysis. A view of the molecular geometry of this compound is shown in Figure 1. The $\mathrm{W}-\mathrm{C}(4)$ distance $(2.135(9) \AA)$ is slightly shorter than that of a regular $\mathrm{W}-\mathrm{C}\left(\mathrm{sp}^{3}\right)$ single bond, ${ }^{10}$ and the $C(4) \equiv C(4 a)$ distance of $1.21(2) \AA$ is very close to the expected value for an organic $C \equiv C$ triple bond, ${ }^{11}$ indicating a dimetallaalkyne with the $M-C \equiv C-M$ form, instead of the alternative "dicarbide" $\mathrm{M}=\mathrm{C}=\mathrm{C}=\mathrm{M}$ form found in the Ta system. ${ }^{12}$ Very similar distances are found in the acetylide complexes

(9) (a) Keim, W. Catalysis in C1 Chemistry; D. Reidel: Dordrecht, The Netherlands, 1983. (b) Anderson, R. B. The Fischer-Tropsch Synthesis; Academic Press: London, 1984. (c) Somorjai, G. A. Introduction of Surface Chemistry and Catalysis; J ohn Wiley \& Sons: New York, 1994.

(10) Templeton, J. L.; Winston, P. B.; Ward, B. C. J . Am. Chem. Soc. 1981, 103, 7713 .

(11) Allene, F. H.; Kennard, O.; Watson, D. G.; Brammer, L.; Orpen, A. G.; Taylor, R. J. Chem. Soc., Perkin Trans. 2 1987, S1-S19.

(12) Neithammer, D. R.; Lapointe, R. E.; Wheeler, R. A.; Richeson, D. S.; Van Duyne, G. D.; Wolczanski, P. T. J . Am. Chem. Soc. 1989, 111, 9056.

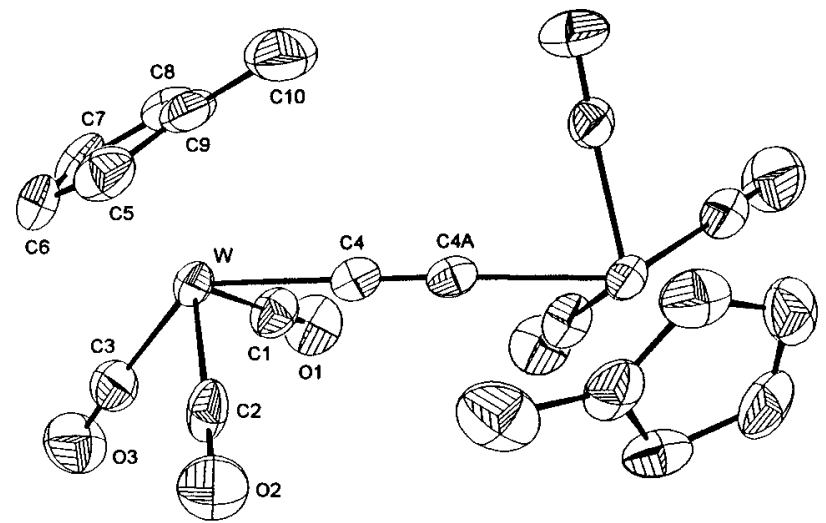

Figure 1. ORTEP drawing of $\left(\mathrm{C}_{5} \mathrm{H}_{4} \mathrm{Me}\right)_{2}(\mathrm{CO})_{6} \mathrm{~W}_{2}(\mu-\mathrm{C} \equiv \mathrm{C})$ (2) with thermal ellipsoids shown at the $50 \%$ probability level. Selected bond distances $(\AA)$ and bond angles (deg) are as follows: $\mathrm{W}-\mathrm{C}(4), 2.135(9) ; \mathrm{C}(4)-\mathrm{C}(4 \mathrm{a}), 1.216(19)$; $\mathrm{W}-\mathrm{C}(4)-\mathrm{C}(4 \mathrm{a}), 176.4(8)$.

of $(\mathrm{CO})_{10} \operatorname{Re}_{2}(\mu-\mathrm{C} \equiv \mathrm{C})(1.19(3) \AA),{ }^{13} \mathrm{Cp}_{3}\left(\mathrm{PMe}_{3}\right)_{2} \mathrm{ClRuZr}-$ $(\mu-\mathrm{C} \equiv \mathrm{C}) \quad(1.25(2) \quad \AA),{ }^{14} \quad\left(\mathrm{C}_{5} \mathrm{Me}_{5}\right)\left(\mathrm{PPh}_{3}\right)(\mathrm{NO}) \mathrm{Re}(u-$ $\mathrm{C} \equiv \mathrm{C}) \mathrm{Pd}(\mathrm{PEt})_{2}{ }_{2} \mathrm{Cl},(1.21(1) \AA),{ }^{15}$ and $\left[\mathrm{Cl}\left(\mathrm{PPh}_{3}\right)_{2} \mathrm{Pt}\right]_{2}(u-$ $\mathrm{C} \equiv \mathrm{C}),(1.221(9) \AA) .{ }^{16}$ The $\mathrm{W}-\mathrm{C}(4) \equiv \mathrm{C}(4 \mathrm{a})$ bond angle in $\mathbf{2}^{\prime}\left(176.4(8)^{\circ}\right)$ differs only slightly from $180^{\circ}$. We have previously reported in our preliminary communication the structure of $\mathbf{2}$. All other bond distances and angles lie in the expected range and deserve no further comment. Complex $\mathbf{2}$ has also been reported as a trace product from the reaction of $\mathrm{ClC} \equiv \mathrm{CCl}$ with $\mathrm{Cp}(\mathrm{CO})_{3} \mathrm{~W}^{-} .17$ Great interest has focused on the chemistry of these $\mu$-ethynediyl compounds in past five years. ${ }^{18}$

Formation of complex $\mathbf{2}$ can be envisaged as proceeding via the following steps: The initial reaction of $\mathrm{CH}_{2} \mathrm{l}_{2}$ with 1 presumably gives an unobserved dinuclear $\mu$-methylene complex, $\mathrm{Cp}_{2}(\mathrm{CO})_{6} \mathrm{~W}_{2}\left(\mu-\mathrm{CH}_{2}\right)$ (4), which undergoes $\mathrm{CO}$ insertion to give a ketene intermediate. The subsequent "formal dehydration" reaction and $\mathrm{CO}$ abstraction from the other $\mathrm{Cp}(\mathrm{CO})_{3} \mathrm{~W}$ moiety satisfactorily account for the formation of $\mathbf{2}$. The low yield of this reaction may thus be interpreted in terms of this CO abstraction step. The transformation of an acyl ligand in a Re complex into a vinylideneligand by triflic anhydride was reported ${ }^{19}$ by Hughes and his co-workers. The CO-induced conversion of $\eta^{1}$-ketenyl ligands into alkynyl ligands by a deoxygenation reaction has been reported, ${ }^{20}$ but its mechanism is unknown. The reverse

(13) (a) Beck, W.; Niemer, B.; Mreimair, J .; Heidrich, J . J . Organomet. Chem. 1989, 372, 79. (b) Heidrich, J .; Steimann, M.; Appel, M. Beck, W. Organometallics 1990, 9, 1296.

(14) Lemke, F. R.; Szalda, D. J .; Bullock, R. M. J . Am. Chem. Soc. 1991, 113, 8466

(15) Weng, W.; Bartik, T.; Brady, M.; Bartik, B.; Ramsden, J. A.; Arif, A. M.; Gladysz, J. A. J .' Am. Chem. Soc. 1995, 117, 11922.

(16) Sünkel, K.; Birk, U.; Robl, C. Organometallics 1994, 13, 1679.

(17) Ustynyuk, N. A.; Yinogradova, V. N.; Kravtsov, D. N. Metalloorg. Khim. 1988, 1, 85; Organomet. Chem. USSR (Engl. Transl.) 1988, 1,45 .

(18) (a) Chisholm, M. H. Angew. Chem., Int. Ed. Engl. 1991, 30, 673. (b) Koutsantonis, G. A.; Selegue, J . P. J . Am. Chem. Soc. 1991, 113, 2316. (c) Beck, W.; Niemer, B.; Wieser, M. Angew. Chem., Int. Ed. Engl. 1993, 32, 923. (d) Akita, M.; Morooka, Y. Bull. Chem. Soc. J pn. 1995, 68, 420. (e) De Angelis, S.; Solari, E.; Floriani, C.; ChiesiVilla, A.; Rizzoli, R. Angew. Chem., Int. Ed. Engl. 1995, 34, 1092. (f) Belanzoni, P.; Re, N.; Rosi, M.; Sgamellotti, A.; Floriani, C. Organometallics 1996, 15, 4264.

(19) Boland-Lussier, B. E.; Churchill, M. R.; Hughes, R. P.; Rheingold, A. L. Organometallics 1982, 1, 628.

(20) (a) Kreissl, F. R.; Eberl, K.; U edelhoven, W. Angew. Chem., Int. Ed. Engl. 1978, 17, 860. (b) Eberl, K.; Uedelhoven, W.; Wolfggruber, M.; Kreissl, F. R. Chem. Ber. 1982, 115, 504. 
Scheme 1

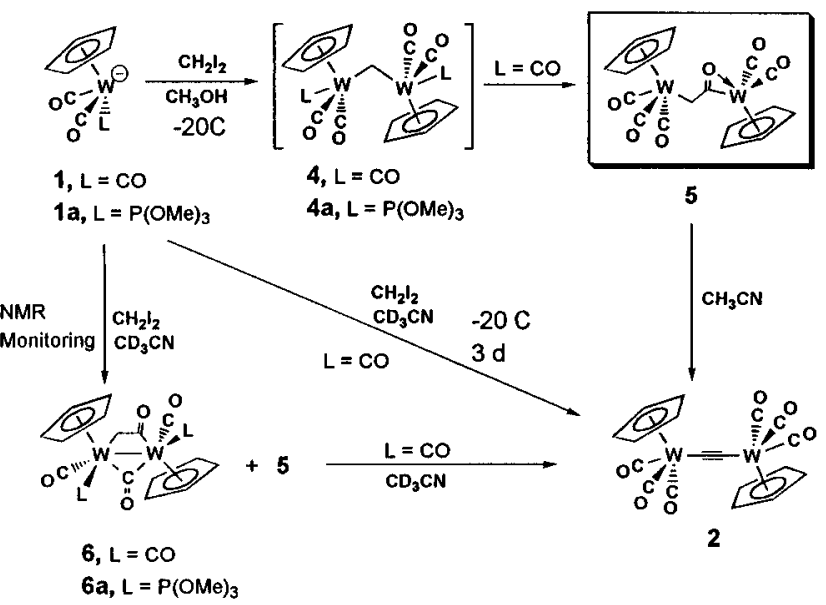

reaction has been observed in the transformation of metal acetylide to metal acyl complex. ${ }^{21}$

Isolation of an 0-Coordinated Ketene Complex. Our attempts to prepare precursors of $\mathbf{2}$ led to isolation of an O-coordinated ketene complex. Since the solvent used for this reaction plays an important role in determining the product, the attempted reactions are therefore carried out in several different solvents. An explicit intermediate is isolated from the reaction carried out in $\mathrm{MeOH}$. Treatment of $\mathbf{1}$ with $\mathrm{CH}_{2} \mathrm{I}_{2}$ in methanol at $-20{ }^{\circ} \mathrm{C}$ affords in $49 \%$ yield a dark red product identified as a dinuclear ketene complex, $\mathrm{Cp}_{2}(\mathrm{CO})_{5} \mathrm{~W}_{2}\left(\eta^{1}, \eta^{2}, \mu-\mathrm{CH}_{2} \mathrm{CO}\right)$ (5). The same product is also isolated from the reaction carried out in ethanol but with a lower yield. The analogous complex $\mathrm{Cp}_{2}^{\prime}(\mathrm{CO})_{5} \mathrm{~W}_{2}\left(\eta^{1}, \eta^{2}, \mu-\mathrm{CH}_{2} \mathrm{CO}\right)\left(5^{\prime}\right)$ is prepared similarly in $\mathrm{MeOH}$ at $-20^{\circ} \mathrm{C}$ in $52 \%$ yield and in $\mathrm{EtOH}$ with a lower yield. Complex $\mathbf{5}^{\prime}$ is relatively more stable than 5. The two methylene protons of $\mathbf{5}$ are replaced by $\mathrm{D}$ atoms for the reaction carried out in $\mathrm{CH}_{3} \mathrm{OD}$. But the $\mathrm{CH}_{2}$ protons of $\mathbf{5}$ and $\mathbf{5}^{\prime}$ are not exchangeable with $\mathrm{CH}_{3} \mathrm{OD}$, indicating that an exchange process occurs at the methylene complex. In addition to the structure of $\mathbf{5}$, there is an alternative structure $\mathbf{6}$ depicted in Scheme 1 , obeying the 18-electron rule. On the basis of the spectroscopic data, chemical reactivities, and X-ray structure determination, complex $\mathbf{5}$ in its solid state contains a bridging ketene with the $\eta^{2}$-CO unit bonded to one of the tungsten centers. ${ }^{22}$ However, when the reaction carried out in $\mathrm{CD}_{3} \mathrm{CN}$ is monitored by $\mathrm{NMR}$ spectroscopy at low temperature, the alternative species $\mathbf{6}$ is also observed. The cyclic structure of $\mathbf{6} \mathrm{imposes}$ restriction for rotation of the $\mathrm{W}-\mathrm{C}$ bond, making the two methylene protons inequivalent. Thus in the ${ }^{1} \mathrm{H}$ NMR spectra characteristic differences in the $\mathrm{CH}_{2}$ resonances of $\mathbf{5}$ and $\mathbf{6}$ would be expected: a singlet

(21) Bruce, M. I.; Swincer, A. G. Aust. J . Chem. 1980, 33, 1471.

(22) (a) Fachinetti, G.; Floriani, C.; Stoeckli-Evans, H. J . Chem. Soc., Dalton Trans. 1977, 2297. (b) Manriquez, J. M.; McAlister, D. R.; Sanner, R. D.; Bercaw, J. E. J . Am. Chem. Soc. 1978, 100, 2716. (c) Wolczanski, P. T.; Bercaw, J. E. Acc. Chem. Res. 1980, 13, 121. (d) Richmond, T. G.; Basolo, F.; Schriver, D. F. Inorg. Chem. 1982, 21, 1272. (e) LaCroce, S. J .; Cutler, A. R. J . Am. Chem. Soc. 1982, 104 2312. (f) Erker, G. Acc. Chem. Res. 1984, 17, 103. (g) Durfee, L. D.; Rothwell, I. P. Chem. Rev. 1988, 88, 1059. (h) Gamble, A. S.; White, P. S.; Templeton, J . L. Organometallics 1991, 10, 693. (i) Contreras, L.; Monge, A.; Pizzano, A.; Ruiz, C.; Sanchez, L.; Carmona, E. Organometallics 1992, 11, 3971. (j) Kriessl, W. J ; Sieber, W. J.; Wolfggruber, M.; Riede, J. Angew. Chem., Int. Ed. Engl. 1994, 23, 640. (k) Conejo, M. del M.; Pizzano, A.; Sanchez, L.J .; Carmona, E.J . Chem. Soc., Dalton Trans. 1996, 3687. resonance is expected for the $\mathrm{CH}_{2}$ of 5 because of free rotation of the $\mathrm{W}-\mathrm{C}$ bond and an $\mathrm{AB}$ type pattern for that of $\mathbf{6}$. Indeed in the ${ }^{1} \mathrm{H}$ NMR spectrum of $\mathbf{5}$, the methylene protons appear as a broad singlet resonance (with tungsten satellites) at $\delta 3.41$ and the resonances at $\delta 5.61$ and 5.46 are assigned to the $C p$ groups. The fact that the methylene protons display a singlet resonance indicates a noncyclic structure of the ketene unit for 5. At $-40{ }^{\circ} \mathrm{C}$, restricted rotation of the $\mathrm{W}-\mathrm{CH}_{2}$ bond causes the singlet resonance to form two doublet resonances at $\delta 3.13$ and 3.56 with $\mathrm{J} \mathrm{H}-\mathrm{H}=3.4 \mathrm{~Hz}$ in the ${ }^{1} \mathrm{H}$ spectrum. The structure of $\mathbf{5}$ is al so consistent with its IR spectral data: in addition to the absorption bands at 2020,1922, 1903, and $1827 \mathrm{~cm}^{-1}$ assignable to the stretching of the terminal $\mathrm{CO}$ group, an Ocoordinated $v_{\mathrm{C}=0}$ stretching is observed at $1437 \mathrm{~cm}^{-1}$, much lower than the stretching absorption of a free $\mathrm{C}=\mathrm{O}$ group.

When monitored by ${ }^{1} \mathrm{H}$ NMR spectroscopy, the reaction of 1 with $\mathrm{CH}_{2} \mathrm{I}_{2}$ in $\mathrm{CD}_{3} \mathrm{CN}$ at $-25{ }^{\circ} \mathrm{C}$ is found to yield three complexes, each containing diastereotopic methylene protons with their resonances appearing at $\delta 3.11,3.52\left(\mathrm{~J} \mathrm{H}-\mathrm{H}^{2}=3.7 \mathrm{~Hz}\right), 2.08,2.23(\mathrm{~J} \mathrm{H}-\mathrm{H}=7.5 \mathrm{~Hz})$, and 2.24, $2.62(\mathrm{~J} \mathrm{H}-\mathrm{H}=6.6 \mathrm{~Hz})$ with a ratio of $2: 1: 1$. The first set is almost identical to the low-temperature NMR data of $\mathbf{5}$ (the slight variation may be due to the solvent effect), and the other two sets at the upper field region are believed to be due to isomers of the C,C-bonded ketene complex 6 with a bridging $\mathrm{CO}$ ligand. The upfield chemical shifts of the $\mathrm{CH}_{2}$ protons of $\mathbf{6}$ are similar to those of a Ru complex.22 Thus we can conclude that the proposed $\mathbf{4}$ undergoes $\mathrm{CO}$ insertion to give a mixture of $\mathbf{5}$ and $\mathbf{6}$ in $\mathrm{CH}_{3} \mathrm{CN}$ with $\mathbf{6}$ being much less stable. From a variable-temperature experiment we could not tell if the transformation between $\mathbf{6}$ and 5 would ever occur. In the $\mathrm{CD}_{3} \mathrm{OD}$ solvent system, dueto the deuterium exchange of the methylene protons and many other side products formed, we could not firmly establish the presence of $\mathbf{6}$. Interestingly, without $\mathrm{CH}_{3} \mathrm{CN}$, no acetylide complex could be observed. The "formal dehydration" of the ketene group thus requires oxygen coordination and the presence of $\mathrm{CH}_{3} \mathrm{CN}$.

Recrystallization of $\mathbf{5}^{\prime}$ from hexane gives single crystals suitable for X-ray diffraction analysis. The molecular geometry and labeling scheme are shown in Figure 2. The two $\mathrm{W}$ atoms are connected by a bent $\mu, \eta^{1}, \eta^{2}$ ketene bridge with $\mathrm{W}(1)-\mathrm{C}(6)-\mathrm{C}(7)$ and $\mathrm{W}(2)-\mathrm{C}(7)-$ $\mathrm{C}(6)$ angles of 154.9(19) and 109.7(17) ${ }^{\circ}$, respectively. Coordination of the oxygen atom is clearly shown, with a $W(1)-O(6)$ distance of $2.19(2) \AA$, comparable to the $\mathrm{W}(1)-\mathrm{C}(6)$ distance of $2.10(3) \AA$. The slightly shorter $C(6)-C(7)$ distance of $1.39(4) \AA$ is probably due to this oxygen coordination. The two metal centers exist as mutually independent mononuclear states, and no evidence for metal -metal interaction is detected. Photolysis of $\mathbf{5}$ would not yield the proposed dimetallacyclopropane complex $\mathrm{Cp}_{2}(\mathrm{CO})_{4} \mathrm{~W}_{2}\left(u-\mathrm{CH}_{2}\right)(u-\mathrm{CO})(7)$ but only causes decomposition, indicating that the carbonylation might be an irreversible process due to the oxophilicity of the tungsten metal. Without O-coordination in the Ru system, formation of a dimetallacyclopropane complex $\mathrm{Cp}_{2}(\mathrm{CO})_{2} \mathrm{Ru}_{2}\left(\mu-\mathrm{CH}_{2}\right)(\mu-\mathrm{CO})$ has been obtained by photolysis. ${ }^{23}$ In $\mathbf{5}$ and $\mathbf{5}^{\prime}$, the oxygen atom of the ketene unit is only weakly coordinated to one of

(23) Lin, Y. C. J . Chin. Chem. Soc. 1985, 32, 295. 


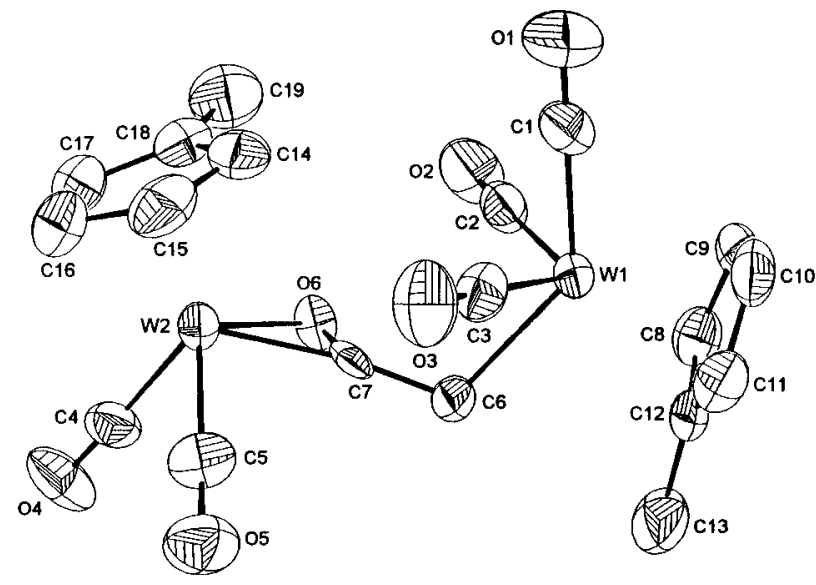

Figure 2. ORTEP drawing of $\left(\mathrm{C}_{5} \mathrm{H}_{4} \mathrm{Me}\right)_{2}(\mathrm{CO})_{5} \mathrm{~W}_{2}\left(\mu-\mathrm{CH}_{2-}\right.$ $\mathrm{CO})\left(5^{\prime}\right)$ with thermal ellipsoids shown at the $50 \%$ probability level. Selected bond distances $(\AA)$ and bond angles (deg) are as follows: $\mathrm{W}(1)-\mathrm{C}(6), 2.325(9) ; \mathrm{W}(2)-\mathrm{O}(6)$, 2.190(6); W(2)-C(7), 2.061(9); C(6)-C(7), 1.43(1); $C(7)-$ $\mathrm{O}(6), 1.27(1) ; \mathrm{W}(2)-C(7)-C(6), 155.6(8) ; C(6)-C(7)-O(6)$, 126.0(8); W(2)-C(7)-O(6), 78.4(5); W(2)-O(6)-C(7), 67.2(5).

thetungsten metal centers. The carbonyl carbon of such a ligand in $\mathbf{5}$ may not have carbene-like character. ${ }^{24}$ Weak coordination of the oxygen atom to tungsten is somewhat surprising, since high oxophilicity has been observed in many tungsten complexes. ${ }^{25}$

Complex $\mathbf{5}$ is a precursor of $\mathbf{2}$, since, upon dissolution in $\mathrm{CH}_{3} \mathrm{CN}, \mathbf{5}$ converts to $\mathbf{2}$ in 10 min at room temperature. On the basis of the stoichiometry, it is not surprising to have a low yield for this transformation. In addition to the "formal dehydration" process that affords 2, cleavage of the ketene unit followed by an intermolecular coupling of two $C_{1}$ units can possibly lead to the $\mathrm{C}_{2}$ product. This possibility is excluded by the following experiment: a mixture of $\mathbf{5}$ and $\mathbf{5}$ in $\mathrm{CH}_{3} \mathrm{CN}$ gives only $\mathbf{2}$ and $\mathbf{2}$ ' with no crossover product $\mathrm{CpCp}^{\prime}(\mathrm{CO})_{6} \mathrm{~W}_{2}(\mu-\mathrm{C} \equiv \mathrm{C})$, indicating that this transformation is an intramolecular process. Conversion of methylene to formaldehyde on rhenium had been reported. ${ }^{26}$

A Ditungsten Methylene Complex. In reactions using the $\mathrm{Cp}(\mathrm{CO})_{3} \mathrm{~W}$ and $\mathrm{Cp}^{\prime}(\mathrm{CO})_{3} \mathrm{~W}$ groups, complex 4 cannot be observed even at low temperature. However, in an experiment using a phosphite-substituted tungsten anion in the preparation, an unstable dinuclear methylene complex with no metal-metal bond is isolated. From the reaction of $\mathrm{Cp}(\mathrm{CO})_{2}\left[\mathrm{P}(\mathrm{OMe})_{3}\right] \mathrm{W}^{-}(\mathbf{l a})$ with $\mathrm{CH}_{2} \mathrm{Br}_{2}$ in THF are isolated the $\mu$-methylene complex $\mathrm{Cp}_{2}(\mathrm{CO})_{4}\left[\mathrm{P}(\mathrm{OMe})_{3}\right]_{2} \mathrm{~W}_{2}\left(\mu-\mathrm{CH}_{2}\right)(\mathbf{4 a})$ as the major product and its carbonylation product $\mathrm{Cp}_{2-}$ $(\mathrm{CO})_{2}\left[\mathrm{P}(\mathrm{OMe})_{3}\right]_{2} \mathrm{~W}_{2}\left(\mu-\mathrm{CH}_{2} \mathrm{CO}\right)(\mu-\mathrm{CO})(6 \mathbf{a})$. Because carbonylation is so facile, $\mathbf{4 a}$ could not be obtained in pure form. When the mixture of $\mathbf{4 a}$ and $\mathbf{6 a}$ is dissolved in $\mathrm{CH}_{3} \mathrm{CN}$, CO insertion of $\mathbf{4 a}$ takes place immediately, yiel ding $6 \mathbf{6}$. If the reaction of $\mathrm{CH}_{2} \mathrm{Br}_{2}$ with $\mathbf{1 a}$ is carried out in $\mathrm{CD}_{3} \mathrm{CN}, 6 \mathrm{a}$ is obtained directly. This carbonylation gives a $\mu, \eta^{1}, \eta^{1}$-ketene group, unlike the $\eta^{1}, \eta^{2}$ bonding mode observed in $\mathbf{5}$. For $\mathbf{4 a}$, the triplet signal at $\delta 2.34(\mathrm{~J}-\mathrm{H}=5.1 \mathrm{~Hz})$ in the ${ }^{1} \mathrm{H}$ NMR spectrum and the triplet resonance at $\delta-50.4(\mathrm{f}-\mathrm{C}=11.2 \mathrm{~Hz})$ in the

(24) Yamamoto, A. Organotransition Metal Chemistry, Fundamental Concepts and Application; Wiley: New York, 1990; p 250.

(25) Mayer, J. M. J . Am. Chem. Soc. 1987, 109, 2826.

(26) Buhro, W. E.; Georgious, S.; Ferndandez, J. M.; Patton, A. T.; Strouse, C. E.; Gladysz, J. A. Organometallics 1986, 5, 956.
Scheme 2

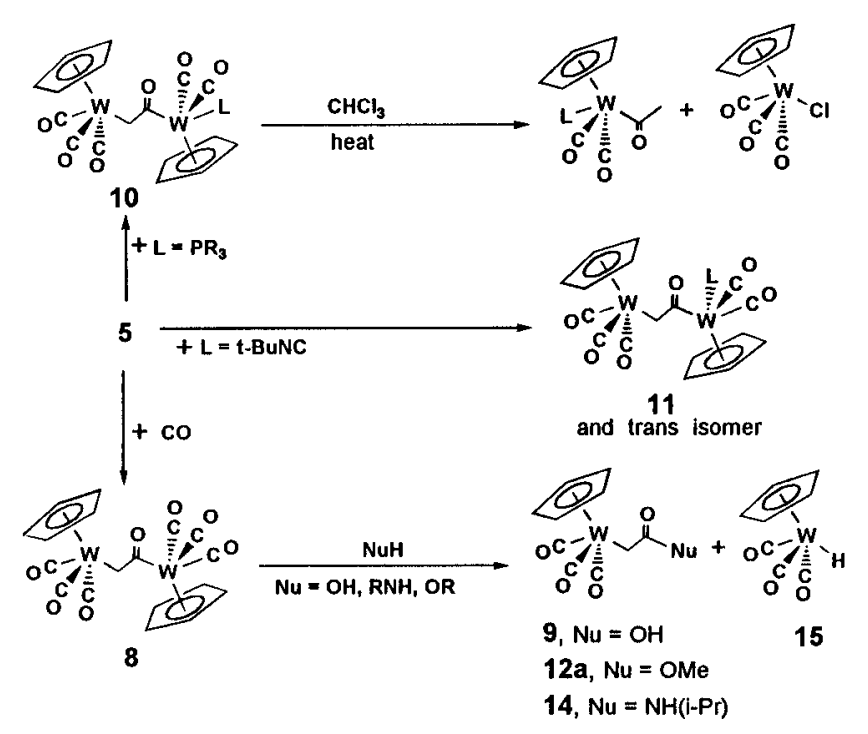

${ }^{13} \mathrm{C}$ NMR spectrum are characteristic for such a $\mathrm{CH}_{2}$ group. ${ }^{7 a} \mathrm{~F}$ or $6 \mathbf{a}$, the two broad doublet resonances at $\delta$ 3.00 and 2.95 in the ${ }^{1} \mathrm{H}$ NMR spectrum assignable to the methylene group reveal the inequivalence of the gem protons, indicating the cyclic structure. Two resonances at $\delta 183.8$ and 158.1 in the ${ }^{31 P}$ NMR spectrum are assigned to the two $\mathrm{P}(\mathrm{OMe})_{3}$ ligands. Better donor ability of the phosphite ligand increases the electron density at the metal center and thus hinders oxygen coordination. The fact that no acetylide complex is observed in the phosphite-substituted system reinforces the concept of the importance of the O-coordination in the formation of an acetylide complex.

Reaction of $\mathbf{5}$ with Donor Ligand. Treatment of 5 with $\mathrm{CO}$ affords $\mathrm{Cp}_{2}(\mathrm{CO})_{6} \mathrm{~W}_{2}\left(\mu-\mathrm{CH}_{2} \mathrm{CO}\right)(\mathbf{8})$; see Scheme 2. Under $1 \mathrm{~atm}$ of $\mathrm{CO}$ pressure, the $\mathrm{CH}_{2} \mathrm{Cl}_{2}$ solution of 5 turned to yellowish-orange within $45 \mathrm{~min}$, and by cooling this solution to $-20{ }^{\circ} \mathrm{C}$, a yellow crystalline product $\mathbf{8}$ is isolated in $55 \%$ yield. The weakly coordinated oxygen atom relinquishes the coordination site for the incoming $\mathrm{CO}$ ligand. In this reaction the temperature control is critical: the optimum yield is obtained at around $25^{\circ} \mathrm{C}$; at a higher temperature or at a temperature below $15{ }^{\circ} \mathrm{C}$, the reaction gives a mixture of compounds, possibly due to the decomposition of 5. The reaction requires anhydrous conditions; i.e., in the presence of water, the reaction yields $\mathrm{Cp}(\mathrm{CO})_{3} \mathrm{WCH}_{2} \mathrm{COOH}$ (9) as a minor product which is formed by the hydrolysis of $\mathbf{8}$. Complex $\mathbf{9}$ could be separated from $\mathbf{8}$ by fractional crystallization. Treatment of $\mathbf{8}$ with dehydration agents such as triflic anhydride does not yield $\mathbf{2}$, further evidence supporting the idea that O-coordination is required for the "formal dehydration" to occur.

In the IR spectrum of 8, the absorption band at 1612 $\mathrm{cm}^{-1}$ is a typical $v_{\mathrm{C}=0}$ stretching of a ketone or an acyl ligand. ${ }^{27}$ In the ${ }^{1} \mathrm{H}$ NMR spectrum, three singlet resonances at $\delta 5.50,5.44$, and 3.20 are assigned to the two $\mathrm{Cp}$ groups and the methylene group, respectively. The ${ }^{13} \mathrm{C}$ resonance of the $\mathrm{CH}_{2}$ group appears at $\delta 22.7$ in the ${ }^{13} \mathrm{C}$ NMR spectrum. Anal ogous complex 8 could

(27) Collman, J . P.; Hegedus, L. S.; Norton, J . R.; Finke, R. G. Principles and Applications of Organotransition Metal Chemistry; University Science Books: Mill Valley, CA, 1987; p 107. 

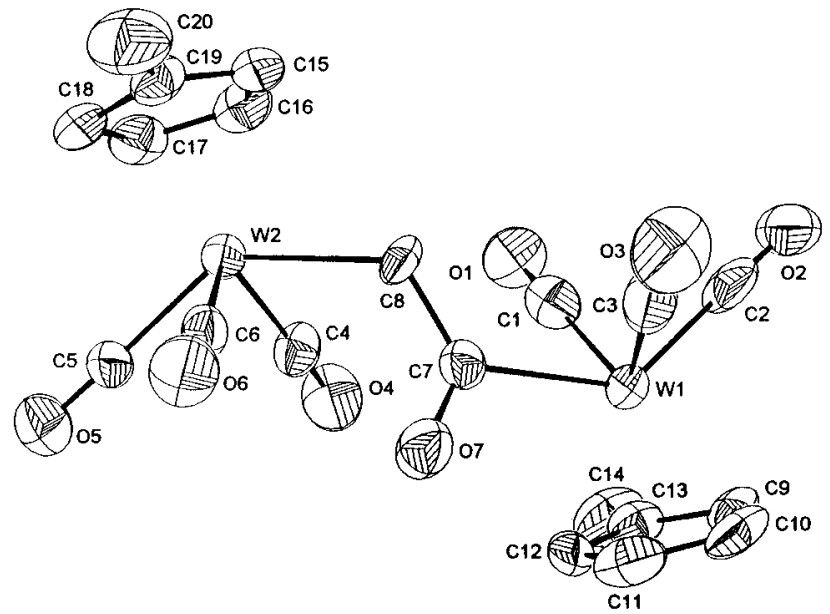

Figure 3. ORTEP drawing of $\left(\mathrm{C}_{5} \mathrm{H}_{4} \mathrm{Me}\right)_{2}(\mathrm{CO})_{6} \mathrm{~W}_{2}\left(\mu-\mathrm{CH}_{2}-\right.$ CO) $\left(\mathbf{8}^{\prime}\right)$ with thermal ellipsoids shown at the $50 \%$ probability level. Selected bond distances $(\AA)$ and bond angles (deg) are as follows: $\mathrm{W}(1)-\mathrm{C}(7), 2.29(1) ; \mathrm{W}(2)-\mathrm{C}(8), 2.27(1)$; $\mathrm{C}(7)-\mathrm{C}(8), 1.49(1) ; \mathrm{C}(7)-\mathrm{O}(7), 1.24(1) ; \mathrm{W}(1)-\mathrm{C}(7)-\mathrm{C}(8)$, 124.0(6); $\mathrm{W}(1)-\mathrm{C}(7)-\mathrm{O}(7), 114.4(7) ; \mathrm{C}(8)-\mathrm{C}(7)-\mathrm{O}(7)$, 121.6(9); $\mathrm{W}(2)-\mathrm{C}(8)-\mathrm{C}(7), 121.9(7)$.

be similarly prepared, and with the same workup procedure, single crystals suitable for $\mathrm{X}$-ray diffraction analysis are obtained. The molecular geometry and the labeling scheme resulting from the analysis are shown in Figure 3. The two $\mathrm{W}-\mathrm{C}$ distances of the ketene ligand are comparable (2.29(1) and 2.27(1) $\AA$ ). The $\mu, \eta^{1}, \eta^{1}$-coordination mode of the ketene is clearly shown since the $\mathrm{O}(7)$ is no longer coordinated to the W(1) metal.

Treatment of $\mathbf{5}$ with $\mathrm{P}(\mathrm{OMe})_{3}$ at $-20^{\circ} \mathrm{C}$ affords the dinuclear ketene complex, trans- $\mathrm{Cp}_{2}(\mathrm{CO})_{5}\left[\mathrm{P}(\mathrm{OMe})_{3}\right] \mathrm{W}_{2}(\mu-$ $\mathrm{CH}_{2} \mathrm{CO}$ ) (10a), in 89\% isol ated yield. The term "trans" refers to the configuration at the $\mathrm{P}(\mathrm{OMe})_{3}$-substituted metal center; see Scheme 2. Spectroscopic data of 10a are consistent with this formulation. In the ${ }^{1} \mathrm{H} N M R$ spectrum, the resonances of the two $\mathrm{Cp}$ groups appear at $\delta 5.44$ and 5.28 , with the latter showing coupling with $\mathrm{P}(\mathrm{OMe})_{3}, \mathrm{~J}-\mathrm{H}=1.3 \mathrm{~Hz}$, a typical coupling constant for a piano stool $\mathrm{Cp}(\mathrm{CO})_{2} \mathrm{LWR}$ structure in a trans configuration; ${ }^{28}$ the resonance at $\delta 3.22$ is assigned to the $\mathrm{CH}_{2}$ of the bridging ketene. Similar reactions are observed for $\mathrm{PEt}_{3}$ and $\mathrm{PPh}_{3}$ giving $\mathrm{Cp}_{2}(\mathrm{CO})_{5}\left(\mathrm{PEt}_{3}\right) \mathrm{W}_{2}\left(\mu-\mathrm{CH}_{2} \mathrm{CO}\right)$ (10b) and $\mathrm{Cp}_{2}(\mathrm{CO})_{5}\left(\mathrm{PPh}_{3}\right) \mathrm{W}_{2}\left(\mu-\mathrm{CH}_{2} \mathrm{CO}\right)(\mathbf{1 0 c})$, respectively. Only the trans isomer is observed for both $\mathbf{1 0 b}$ and ${ }^{10} \mathrm{c}$. The ${ }^{13} \mathrm{C}$ resonances of the $\mathrm{CH}_{2}$ and $\mathrm{CO}$ of the bridging ketene unit appear at $\delta 20-30$ and at $\delta 250$, respectively. Values of the two J w-c coupling constants for the methylene carbon can be obtained from the ${ }^{13} \mathrm{C}$ NMR spectra of $10 \mathbf{a}-\mathbf{c}$ and fall in the range of 30 and $25 \mathrm{~Hz}$.

Treatment of $\mathbf{5}$ with tert-butyl isocyanide al so affords a high yield of $\mathrm{Cp}_{2}(\mathrm{CO})_{5}(\mathrm{t}-\mathrm{BuNC}) \mathrm{W}_{2}\left(u-\mathrm{CH}_{2} \mathrm{CO}\right)(\mathbf{1 1})$; see Scheme 2. Both the trans and cis isomers are generated from the reaction, with a slight excess of the trans product. In the ${ }^{1} \mathrm{H}$ NMR spectra, a singlet resonance at $\delta 3.76$ is assigned to the $\mathrm{CH}_{2}$ for the bridging ketene of the trans isomer and an $A B$ pattern at $\delta 3.60$ and 3.40 with $\mathrm{J} \mathrm{H-H}=13.5 \mathrm{~Hz}$ is assigned to the corresponding $\mathrm{CH}_{2}$ of the cis isomer. In growing crystals suitable for X-ray diffraction analysis, only the trans isomer is

(28) Stack, J . G.; Doney, J . J .; Bergman, R. G.; Heathcock, C. H. Organometallics 1990, 9, 453.

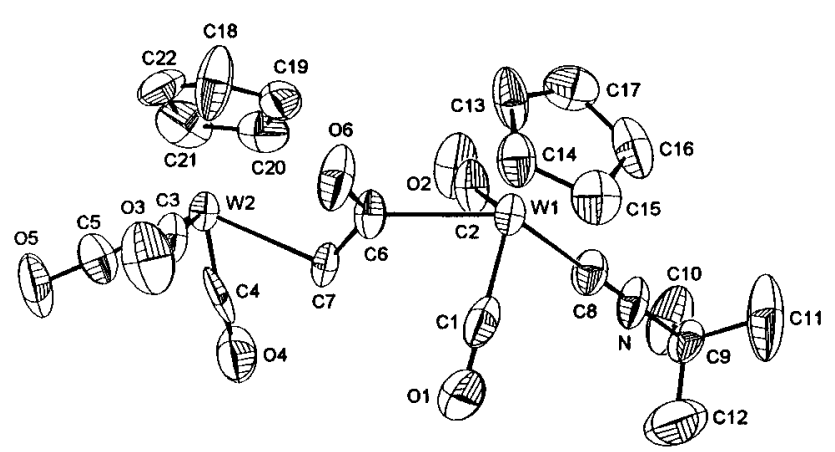

Figure 4. ORTEP drawing of $\mathrm{Cp}_{2}(\mathrm{CO})_{5}\left(\mathrm{CNCMe}_{3}\right) \mathrm{W}_{2}(u$ $\mathrm{CH}_{2} \mathrm{CO}$ ) (11) with thermal ellipsoids shown at the $40 \%$ probability level. Selected bond distances $(\AA)$ and bond angles (deg): W(1)-C(6), 2.29(2); W(1)-C(8), 2.06(2); W(2)$C(7), 2.36(2) ; C(6)-C(7), 1.50(3) ; C(6)-O(6), 1.19(3) ; W(2)-$ $C(7)-C(6), 114.6(14) ; W(1)-C(6)-C(7), 117.9(13) ; W(1)-$ $\mathrm{C}(6)-\mathrm{O}(6), 118.9(15) ; \mathrm{C}(7)-\mathrm{C}(6)-\mathrm{O}(6), 122.9(18) ; \mathrm{W}(1)-$ $\mathrm{C}(8)-\mathrm{N}, 178.9(20) ; \mathrm{C}(8)-\mathrm{N}-\mathrm{C}(9), 176.4(25)$.

obtained. The crystal structure of the trans isomer consists of an ordered arrangement of discrete molecular units, which are seperated by normal van der Waals distances. The mol ecular geometry and labeling scheme are shown in Figure 4 . The $\mu, \eta^{1}, \eta^{1}$-coordination mode of the ketene is clearly shown by the $\mathrm{W}(1)-\mathrm{C}(6)$ distance of 2.29(2) $\AA$ and the $W(2)-C(7)$ distance of 2.36(2) $\AA$. The $C(6)-C(7)$ distance of $1.50(3) \AA$ is comparable to that in $\mathbf{8}^{\prime}$ and slightly longer than that in $\mathbf{5}^{\prime}$. The two $\mathrm{W}$ atoms are connected by a bent $C_{2}$ ketene bridge with $\mathrm{W}(1)-\mathrm{C}(6)-\mathrm{C}(7)$ and $\mathrm{W}(2)-\mathrm{C}(7)-\mathrm{C}(6)$ angles of $117.9(13)$ and $114.6(14)^{\circ}$, respectively. The two metal centers exist as mutual ly independent mononuclear states, and no evidence for metal-metal interaction is detected. Isonitriles form stable transition metal complexes 29 analogous to metal carbonyls. The ketene-bridged complexes $\mathbf{1 0}$ and $\mathbf{1 1}$ are inert and relatively more stable than 8; while the latter decomposes at room temperature, the former complexes are stable. Thermolysis of $10 \mathrm{a}$ in $\mathrm{CHCl}_{3}$ gives the acyl complex $\mathrm{Cp}(\mathrm{CO})_{2}\left[\mathrm{P}(\mathrm{OMe})_{3}\right]-$ $\mathrm{WCOCH}_{3}(\mathbf{1 6 a})$ and $\mathrm{Cp}(\mathrm{CO})_{3} \mathrm{WCl}$.

Reactions of 8 with Nucleophiles. The reaction of 8 with $\mathrm{MeOH}$ in $\mathrm{CH}_{2} \mathrm{Cl}_{2}$ generates $\mathrm{Cp}(\mathrm{CO})_{3} \mathrm{WCH}_{2}$ COOMe (12a, $50 \%$ yield) and $\left[\mathrm{Cp}(\mathrm{CO})_{3} \mathrm{~W}\right]_{2}(\mathbf{1 3}, 26 \%$ yield); see Scheme 2. The other mononuclear complexes $\mathrm{Cp}(\mathrm{CO})_{3} \mathrm{WCH}_{2} \mathrm{COOR}$ (12b, $\mathrm{R}=\mathrm{Et} ; \mathbf{1 2 c}, \mathrm{R}=\mathrm{CH}_{2} \mathrm{Ph}$ ) and $\mathbf{1 3}$ are also obtained from EtOH and $\mathrm{PhCH}_{2} \mathrm{OH}$, respectively, all in high yield. Similarly, treatment of 8 with i-PrN $\mathrm{H}_{2}$ affords $\mathrm{Cp}(\mathrm{CO})_{3} \mathrm{WCH}_{2} \mathrm{CONH}$ (i-Pr) (14, $77 \%$ yield) and 13 as the final product. The ${ }^{13} \mathrm{C}$ resonances of the $\mathrm{CH}_{2}$ group of $\mathbf{1 4}$ appear at the upperfield region $(\delta-10)$ and the amide CO appears at $\delta 180$ in its ${ }^{13} \mathrm{C}$ NMR spectrum. If the reactions are carried out in $\mathrm{C}_{6} \mathrm{D}_{6}$ and monitored by NMR spectroscopy, $\mathrm{Cp}(\mathrm{CO})_{3} \mathrm{WH}(\mathbf{1 5})$ is observed at the initial stage. As mentioned previously, in the presence of water, 8 converts to $\mathbf{9}$ and $\mathbf{1 5}$. The nucleophiles attack the carbonyl carbon of the ketene unit directly forming $\mathbf{9}$, 12, 14, and 15; the latter then dimerizes to give the observed tungsten dimer 13 . In the ${ }^{1} \mathrm{H}$ NMR spectrum of $\mathbf{9}$ two resonances at $\delta 5.52$ and 2.04 are assigned to the $\mathrm{Cp}$ and the $\mathrm{CH}_{2}$ group.

Such a nucleophilic addition does not occur for the substituted ketene complexes $\mathbf{1 0}$ and $\mathbf{1 1}$. It is not

(29) (a) Yamamoto, Y. Coord. Chem. Rev. 1980, 32, 193. (b) Singleton, E.; Oosthuizen, M. E. Adv. Organomet. Chem. 1983, 22, 209. 
surprising to find no nucleophilic addition since the better $\sigma$-donor phosphorus ligand and isonitrile ligand enhance the el ectron density at the carbonyl group and thus hinder addition of the nucleophiles. Also the donor ligands make the $\mathrm{W}-\mathrm{COCH}_{2}$ bond more stable such that, in the thermolytic reaction of $\mathbf{1 0} \mathrm{in} \mathrm{CHCl}_{3}$, cleavage of the $\mathrm{W}-\mathrm{CH}_{2}$ bond leads to the mononuclear complexes $\mathrm{Cp}(\mathrm{CO})_{2} \mathrm{LWCOMe}$ and $\mathrm{Cp}(\mathrm{CO})_{3} \mathrm{WCl}$ in high yield. Reactivity of $\mathbf{5}$ toward nucleophiles is not well defined since attempted nucleophilic additions to $\mathbf{5}$ al ways give complex mixtures. The chemical reactivity of complex $\mathbf{8}$ is somewhat different from that of dinuclear ruthenium complex $\mathrm{Cp}_{2}(\mathrm{CO})_{2} \mathrm{Ru}_{2}\left(\mu-\mathrm{CH}_{2} \mathrm{CO}\right)(\mu$ $\mathrm{CO}){ }^{22}$ In the reactions of $\mathrm{Ru}-$ ketene complexes with nucleophiles, free organic molecules such as $\mathrm{MeCOOH}$ (from $\mathrm{H}_{2} \mathrm{O}$ ) and $\mathrm{MeCOOMe}$ (from $\mathrm{MeOH}$ ) were generally observed as the final products.

Concluding Remark. The reaction of $\mathrm{CH}_{2} \mathrm{I}_{2}$ with $\mathrm{Cp}(\mathrm{CO})_{3} \mathrm{~W}^{-}$gives various products which provide a system to study the rich chemistry of a dinuclear tungsten methylene $C_{1}$ complex with no metal-metal bond. Facile carbonylation is the major reactivity displayed by such a methylene complex. Thus when the reaction is carried out in $\mathrm{MeOH}$ the key O-coordinated $\mu, \eta^{1}, \eta^{2}$-bridging ketene $\mathrm{C}_{2}$ intermediate is obtained. The weakly bonded oxygen atom surrenders the coordination site in the presence of a two-electron donor ligand to form the $\mu, \eta^{1}, \eta^{1}$-bridging ketene. However, such a weak O-coordination is crucial to induce a "formal dehydration" to produce the acetylide complex which is obtainable from the reaction of $\mathrm{CH}_{2} \mathrm{I}_{2}$ with $\mathrm{Cp}(\mathrm{CO})_{3} \mathrm{~W}^{-}$in $\mathrm{MeCN}$ directly. The presence of an electron-donating group in these complexes provides higher stability; hence $C p^{\prime}$ anal ogues and phosphorus ligand substituted complexes are more stable.

\section{Experimental Section}

General Procedures. All manipulations were performed under nitrogen using a vacuum line, a drybox, and standard Schlenk techniques. NMR spectra were recorded on Bruker AC-200 and DMX-500 spectrometers and are reported in units of $\delta$ with residual protons in the solvent as an internal standard $\left(\mathrm{CDCl}_{3}, \delta 7.24 ; \mathrm{CD}_{3} \mathrm{CN}, \delta 1.93 ; \mathrm{C}_{2} \mathrm{D}_{6} \mathrm{CO}, \delta 2.04\right)$. IR spectra were measured on a Perkin-EImer 983 instrument, and frequencies $\left(\mathrm{cm}^{-1}\right)$ were assigned relative to a polystyrene standard. FAB mass spectra were recorded on a J EOL SX102A spectrometer. Elemental analyses and X-ray diffraction studies were carried out at the Regional Center of Analytical Instrument located at the National Taiwan University. $\mathrm{MeOH}$ was distilled from $\mathrm{Mg}$ prior to use. $\mathrm{CH}_{3} \mathrm{CN}$ and $\mathrm{CH}_{2} \mathrm{Cl}_{2}$ were distilled from $\mathrm{CaH}_{2}$. Diethyl ether and THF were distilled from $\mathrm{Na} / \mathrm{ketyl}$. All other solvents and reagents were reagent grade and used as received. $\mathrm{W}(\mathrm{CO})_{6}$ and $\mathrm{PEt}_{3}$ were purchased from Strem Chemical, and $\mathrm{CH}_{2} \mathrm{I}_{2}, \mathrm{CH}_{2} \mathrm{Br}_{2}, \mathrm{P}(\mathrm{OMe})_{3}, \mathrm{PPh}_{3}$, $\mathrm{t}-\mathrm{BuNC}$, i-PrNH${ }_{2}$, and $\mathrm{PhCH}_{2} \mathrm{OH}$ were purchased from Merck; $\mathrm{CH}_{2} \mathrm{I}_{2}$ and $\mathrm{CH}_{2} \mathrm{Br}_{2}$ were distilled in small quantities before use. The complexes $\left[\mathrm{Cp}(\mathrm{CO})_{3} \mathrm{~W}\right]_{2}(\mathbf{1 3}),\left[\mathrm{Cp}^{\prime}(\mathrm{CO})_{3} \mathrm{~W}\right]_{2}(\mathbf{1 3})$, and $\left[\mathrm{Cp}(\mathrm{CO})_{2} \mathrm{P}(\mathrm{OMe})_{3} \mathrm{~W}\right]_{2} \mathrm{Hg}$ were prepared according to the literature methods, ${ }^{30}$ and the metallate anions $\mathrm{Cp}(\mathrm{CO})_{3} \mathrm{~W}^{-}(\mathbf{1})$, $\mathrm{Cp}^{\prime}(\mathrm{CO})_{3} \mathrm{~W}^{-}\left(\mathbf{1}^{\prime}\right)$, and $\mathrm{Cp}(\mathrm{CO})_{2} \mathrm{P}(\mathrm{OMe})_{3} \mathrm{~W}^{-}(\mathbf{l a})$ were prepared from $\mathrm{Na} / \mathrm{Hg}$ reduction of the corresponding tungsten dimers.

Reaction of 1 with $\mathrm{CH}_{2} \mathrm{I}_{2}$ in $\mathrm{CH}_{3} \mathrm{CN}$ at $-20{ }^{\circ} \mathrm{C}$. To a flask containing a solution of $\mathrm{Cp}(\mathrm{CO})_{3} \mathrm{~W}^{-}(3.40 \mathrm{mmol}$, prepared from $\mathrm{Na} / \mathrm{Hg}$ reduction of $1.13 \mathrm{~g}$ of $\mathbf{1 3}$ and used immediately after $\mathrm{Hg}$ was removed) in $15 \mathrm{~mL}$ of $\mathrm{MeCN}$ at $-40^{\circ} \mathrm{C}$ was added

(30) Thomasson, J . E.; Robinson, P. W.; Ross, D. A.; Wojcicki, A. Inorg. Chem. 1971, 10, 2130.
$\mathrm{CH}_{2} \mathrm{I}_{2}(0.135 \mathrm{~mL}, 1.67 \mathrm{mmol})$. The solution was stored at -20 ${ }^{\circ} \mathrm{C}$ for 3 days, and dark red crystalline solids were found in the flask. The solid was filtered and washed with hexane to give $\mathrm{Cp}_{2}(\mathrm{CO})_{6} \mathrm{~W}_{2}(\mu-\mathrm{C} \equiv \mathrm{C})(2)(0.36 \mathrm{~g}, 0.53 \mathrm{mmol})$ in $31 \%$ yield (based on W). Analytically pure $\mathbf{2}$ was recrystallized from slow diffusion of hexane into a concentrated dichloromethane solution at $-20^{\circ} \mathrm{C}$. Spectroscopic data of $\mathbf{2}$ are as follows. IR, $\mathrm{CH}_{2} \mathrm{Cl}_{2}$ : 2034 (m), 2020 (m), 1933 (vs). ${ }^{1} \mathrm{H} \mathrm{NMR,} \mathrm{CDCl}_{3}: 5.54$ (s, Cp). ${ }^{13} \mathrm{C} \mathrm{NMR}, \mathrm{CDCl}_{3}: 233.4,213.3(\mathrm{CO}) ; 101.1$ (C $\left.\equiv \mathrm{C}\right) ; 91.8$ (Cps). MS, FAB (186W): $694\left(\mathrm{M}^{+}\right), 666\left(\mathrm{M}^{+}-\mathrm{CO}\right), 638\left(\mathrm{M}^{+}-\right.$ 2CO), $610\left(\mathrm{M}^{+}-3 \mathrm{CO}\right), 582\left(\mathrm{M}^{+}-4 \mathrm{CO}\right), 554\left(\mathrm{M}^{+}-5 \mathrm{CO}\right)$, $526\left(\mathrm{M}^{+}-6 \mathrm{CO}\right)$. Anal. Calcd for $\mathrm{C}_{18} \mathrm{H}_{10} \mathrm{O}_{6} \mathrm{~W}_{2}: \mathrm{C}, 31.33 ; \mathrm{H}$, 1.46. Found: $\mathrm{C}, 31.24 ; \mathrm{H}, 1.40$. Complex $\mathrm{Cp}_{2}^{\prime}(\mathrm{CO})_{6} \mathrm{~W}_{2}(u-\mathrm{C} \equiv \mathrm{C})$ (2) $(0.31 \mathrm{~g})$ was similarly prepared in $30 \%$ yield (based on W) from 13 (1.00 g, $1.44 \mathrm{mmol})$ and $\mathrm{CH}_{2} \mathrm{l}_{2}(0.111 \mathrm{~mL}, 1.38 \mathrm{mmol})$. Spectroscopic data of $\mathbf{2}$ are as follows. IR, $\mathrm{CH}_{2} \mathrm{Cl}_{2}: 2034(\mathrm{~m})$, 2019 (m), 1918 (vs). ${ }^{1} \mathrm{H} \mathrm{NMR}, \mathrm{CDCl}_{3}$ : 5.43-5.37 (m, 8H, CH); 2.58 (s, 6H, 2Me). ${ }^{13} \mathrm{C} \mathrm{NMR}, \mathrm{CD}_{3} \mathrm{CN}: 235.0,215.9$ (CO); 106.3 $(\mathrm{C} \equiv \mathrm{C}) ; 94.4-88.6\left(\mathrm{C}_{5} \mathrm{H}_{4}\right) ; 14.8(\mathrm{Me}) . \mathrm{MS}, \mathrm{FAB}: 722\left(\mathrm{M}^{+}\right), 694$ $\left(\mathrm{M}^{+}-\mathrm{CO}\right), 666\left(\mathrm{M}^{+}-2 \mathrm{CO}\right), 638\left(\mathrm{M}^{+}-3 \mathrm{CO}\right), 610\left(\mathrm{M}^{+}-4 \mathrm{CO}\right)$, $582\left(\mathrm{M}^{+}-5 \mathrm{CO}\right), 554\left(\mathrm{M}^{+}-6 \mathrm{CO}\right)$. Anal. Calcd for $\mathrm{C}_{20} \mathrm{H}_{14} \mathrm{O}_{6} \mathrm{~W}_{2}$ : C, 33.46; $\mathrm{H}, 1.96$. Found: C, 33.51; $\mathrm{H}, 2.01$.

Reaction of 1 with Excess $\mathrm{CH}_{2} \mathrm{l}_{2}$ in THF. To a solution of $\mathbf{1}$ prepared from $\mathbf{1 3}(0.56 \mathrm{~g}, 0.84 \mathrm{mmol})$ in $20.0 \mathrm{~mL}$ of THF was added $\mathrm{CH}_{2} \mathrm{I}_{2}(0.20 \mathrm{~mL}, 2.48 \mathrm{mmol})$ at $-20{ }^{\circ} \mathrm{C}$, and in 2 days the color turned to dark red; then the solvent was removed under vacuum. The residue was extracted with $3 \times$ $15 \mathrm{~mL}$ of $1: 1$ hexane/ $\mathrm{CH}_{2} \mathrm{Cl}_{2}$ and recrystallized to give the product $\mathrm{Cp}(\mathrm{CO})_{3} \mathrm{WCH}_{2} \mathrm{l}$ (3) $(0.51 \mathrm{~g}, 1.07 \mathrm{mmol})$ in $64 \%$ yield. The solution part obtained from recrystallization al so contains $\mathrm{Cp}(\mathrm{CO})_{3} \mathrm{WCH}_{3}$ and $\mathrm{Cp}(\mathrm{CO})_{3} \mathrm{WI}$ as two minor products (ca. 10\%). Spectroscopic data of $\mathbf{3}$ are as follows. IR, $\mathrm{C}_{6} \mathrm{H}_{6}: 2025$ (s), 1927 (vs) $v$ (CO). ${ }^{1} \mathrm{H} ~ N M R, \mathrm{CD}_{3} \mathrm{CN}: 5.67$ (s, 5H, Cp); 3.23 $\left(\mathrm{CH}_{2}\right) .{ }^{13} \mathrm{C} \mathrm{NMR}, \mathrm{CD}_{3} \mathrm{CN}: 229.8,219.0(\mathrm{CO}) ; 95.2(\mathrm{Cp}) ;-35.8$ $\left(\mathrm{J} \mathrm{w}-\mathrm{C}=49.3 \mathrm{~Hz}, \mathrm{CH}_{2}\right)$. MS, FAB: $476\left(\mathrm{M}^{+}\right), 448\left(\mathrm{M}^{+}-\mathrm{CO}\right)$, $420\left(\mathrm{M}^{+}-2 \mathrm{CO}\right), 392\left(\mathrm{M}^{+}-3 \mathrm{CO}\right), 349\left(\mathrm{M}^{+}-\mathrm{I}\right), 335\left(\mathrm{M}^{+}-\right.$ $\left.\mathrm{CH}_{2} \mathrm{l}\right)$. Anal. Calcd for $\mathrm{C}_{9} \mathrm{H}_{7} \mathrm{O}_{3} \mathrm{IW}$ : C, 22.81; $\mathrm{H}, 1.49$. Found: C, 22.96; H, 1.65 .

Isolation of Methylene Complex from Reaction of la with $\mathbf{C H}_{2} \mathbf{B r}_{2}$ in THF. To $20.0 \mathrm{~mL}$ of a THF solution of $\mathbf{l a}$ $(0.53 \mathrm{~g}, 1.17 \mathrm{mmol})$ at $-45^{\circ} \mathrm{C}$ was added $\mathrm{CH}_{2} \mathrm{Br}_{2}(0.12 \mathrm{~g})$. The solution was stirred at $-20^{\circ} \mathrm{C}$ until the starting material was completely consumed. The col or of the solution turned from yellow to deep red. The solvent was then removed under vacuum, and the product was extracted with $2 \times 10 \mathrm{~mL}$ of benzene. After removal of the solvent the residue contains $\mathrm{Cp}_{2}(\mathrm{CO})_{4}\left[\mathrm{P}(\mathrm{OMe})_{3}\right]_{2} \mathrm{~W}_{2}\left(\mu-\mathrm{CH}_{2}\right)(\mathbf{4 a})$ as the major product and $\mathrm{Cp}_{2}(\mathrm{CO})_{2}\left[\mathrm{P}(\mathrm{OMe})_{3}\right]_{2} \mathrm{~W}_{2}\left(\mu-\mathrm{CH}_{2} \mathrm{CO}\right)(\mu-\mathrm{CO})(6 \mathbf{a})$ as the minor product (5:1 from the ${ }^{1} \mathrm{H}$ NMR data) in $36 \%$ total yield. An attempt to purify $\mathbf{4 a}$ by careful recrystallization from benzene at $10{ }^{\circ} \mathrm{C}$ gave a mixture of $\mathbf{4 a}$ and $\mathbf{6 a}$ in a 10:1 ratio. Spectroscopic data of $\mathbf{4 a}$ are as follows. IR, $\mathrm{C}_{6} \mathrm{H}_{6}$ : 1920 (s), 1858 (vs) $v(\mathrm{CO}) .{ }^{1} \mathrm{H}$ NMR, $\mathrm{C}_{6} \mathrm{D}_{6}: 5.07$ (s, 10H, Cp); 3.37 (d, $\left.\mathrm{J}_{\mathrm{P}-\mathrm{H}}=11.6 \mathrm{~Hz}, 18 \mathrm{H}, \mathrm{Me}\right) ; 2.33\left(\mathrm{t}, \mathrm{J} \mathrm{P}-\mathrm{H}=5.1 \mathrm{~Hz}, 2 \mathrm{H}, \mathrm{CH}_{2}\right)$. ${ }^{13} \mathrm{C} N M R, C_{6} D_{6}: 228.0(\mathrm{~d}, \mathrm{~J} \mathrm{p}-\mathrm{C}=25.4 \mathrm{~Hz}, \mathrm{CO}) ; 91.7$ (2 Cps); $52.4\left(\mathrm{~d}, \mathrm{~J}_{\mathrm{P}-\mathrm{C}}=4.9 \mathrm{~Hz}, \mathrm{Me}\right) ;-50.4\left(\mathrm{t}, \mathrm{J} \mathrm{p}-\mathrm{C}=11.2 \mathrm{~Hz}, \mathrm{CH}_{2}\right.$ ). MS, FAB: $876\left(\mathrm{M}^{+}\right), 848\left(\mathrm{M}^{+}-\mathrm{CO}\right), 820\left(\mathrm{M}^{+}-2 \mathrm{CO}\right)$. Complex $6 \mathbf{a}$ was obtained by dissolving the mixture of $\mathbf{4 a}$ and $\mathbf{6 a}$ in $\mathrm{CH}_{3} \mathrm{CN}$. Spectroscopic data of $\mathbf{6 a}$ are as follows. IR, $\mathrm{CH}_{3} \mathrm{CN}: 1950$ (s), 1863 (vs), 1764 (m) $v(\mathrm{CO}) .{ }^{1} \mathrm{H}$ NMR, 250 $\mathrm{K}, \mathrm{CD}_{3} \mathrm{CN}$ : $5.28\left(\mathrm{~d}, \mathrm{~J}_{\mathrm{P}-\mathrm{H}}=0.8 \mathrm{~Hz}, 5 \mathrm{H}, \mathrm{Cp}\right) ; 5.24$ (d, J $\mathrm{P}-\mathrm{H}=$ $1.8 \mathrm{~Hz}, 5 \mathrm{H}, \mathrm{Cp}) ; 3.57\left(\mathrm{~d}, \mathrm{~J}_{\mathrm{P}-\mathrm{H}}=11.7 \mathrm{~Hz}, 9 \mathrm{H}, \mathrm{Me}_{3}\right) ; 3.53$ (d, $\left.\mathrm{J} \mathrm{P}-\mathrm{H}=11.7 \mathrm{~Hz}, 9 \mathrm{H}, \mathrm{Me}_{3}\right) ; 3.00,2.95(\mathrm{~d}, \mathrm{br}, \mathrm{J} \mathrm{H-H}=6.2 \mathrm{~Hz}, 2 \mathrm{H}$, $\mathrm{CH}_{2}$ ). ${ }^{31} \mathrm{P} \mathrm{NMR}, 250 \mathrm{~K}, \mathrm{CD}_{3} \mathrm{CN}: 183.8(\mathrm{~J}-\mathrm{w}=542.8 \mathrm{~Hz})$; $158.1(\mathrm{~J}-\mathrm{w}=370.3 \mathrm{~Hz})$. 6a was also observed when the reaction of $\mathrm{CH}_{2} \mathrm{Br}_{2}$ with $\mathbf{l a}$ at $-20^{\circ} \mathrm{C}$ in $\mathrm{CD}_{3} \mathrm{CN}$ was monitored by ${ }^{1} \mathrm{H}$ NMR spectroscopy.

Reaction of $\mathbf{1}$ with $\mathbf{C H}_{2} \mathbf{I}_{2}$ in $\mathbf{M e O H}$. A sample of $\mathbf{1}$ prepared from $\mathrm{Na} / \mathrm{Hg}$ reduction of $13(1.41 \mathrm{~g}, 2.11 \mathrm{mmol})$ was dissolved in $30.0 \mathrm{~mL}$ of $\mathrm{CH}_{3} \mathrm{OH}$ at $-20^{\circ} \mathrm{C}$. Addition of $\mathrm{CH}_{2} \mathrm{I}_{2}$ $(0.168 \mathrm{~mL}, 2.08 \mathrm{mmol})$ via a syringe caused formation of dark red precipitates in 3 days at $-20^{\circ} \mathrm{C}$, and the resulting solution 
was filtered. The precipitates were washed with $3 \times 30 \mathrm{~mL}$ of hexane, giving the product $\mathrm{Cp}_{2}(\mathrm{CO})_{5} \mathrm{~W}_{2}\left(\eta^{1}, \eta^{2}, \mu-\mathrm{CH}_{2} \mathrm{CO}\right)(5)$ $(0.70 \mathrm{~g}, 1.03 \mathrm{mmol})$ in $49 \%$ yield. Spectroscopic data of 5 are as follows. IR, KBr: 2020 (m), 1922 (vs), 1903 (sh), 1827 (m), $1437(\mathrm{~m}) v(\mathrm{CO}) .{ }^{1} \mathrm{H} \mathrm{NMR}, \mathrm{CDCl}_{3}: 5.61$ (s, 5H, Cp); $5.46(\mathrm{~s}$, $5 \mathrm{H}, \mathrm{Cp}) ; 3.41\left(\mathrm{br}, 2 \mathrm{H}, \mathrm{CH}_{2}\right)$. ${ }^{1} \mathrm{H} N M R, 233 \mathrm{~K}, \mathrm{C}_{2} \mathrm{D}_{6} \mathrm{CO}: 6.01$, 5.71 (s, Cps); $3.56\left(\mathrm{~d}, \mathrm{~J}-\mathrm{H}=3.4 \mathrm{~Hz}, 1 \mathrm{H}, \mathrm{CH}_{2}\right) ; 3.13(\mathrm{~d}, \mathrm{~J} \mathrm{H}-\mathrm{H}$ $\left.=3.4 \mathrm{~Hz}, 1 \mathrm{H}, \mathrm{CH}_{2}\right) .{ }^{13} \mathrm{C} \mathrm{NMR}, \mathrm{CDCl}_{3}: 252.8\left(\mathrm{CH}_{2} \mathrm{CO}\right), 240.0$, 227.2, 216.0 (CO); 93.3, $92.3(2 \mathrm{Cps}) ;-5.46\left(\mathrm{CH}_{2}\right)$. MS, FAB: $684\left(\mathrm{M}^{+}\right), 656\left(\mathrm{M}^{+}-\mathrm{CO}\right)$. Anal. Calcd for $\mathrm{C}_{17} \mathrm{H}_{12} \mathrm{O}_{6} \mathrm{~W}_{2}: \mathrm{C}$, 30.03; H, 1.78. Found: C, 30.21; H, 1.98. Complex $\mathrm{Cp}_{2}^{\prime}(\mathrm{CO})_{5} \mathrm{~W}_{2}\left(\eta^{1}, \eta^{2}, \mu-\mathrm{CH}_{2} \mathrm{CO}\right) \quad\left(5^{\prime}\right) \quad(0.60 \mathrm{~g}, 0.84 \mathrm{mmol})$ was similarly prepared in $52 \%$ yield from the reaction of $\mathbf{1}$ (prepared from $\mathrm{Na} / \mathrm{Hg}$ reduction of $\mathbf{1 3}^{\prime}(1.12 \mathrm{~g}, 1.62 \mathrm{mmol})$ ) with $\mathrm{CH}_{2} \mathrm{I}_{2}(0.129 \mathrm{~mL}, 1.60 \mathrm{mmol})$. Spectroscopic data of $\mathbf{5}^{\prime}$ are as follows. IR, $\mathrm{CH}_{2} \mathrm{Cl}_{2}$ : 2027 (m), 1927 (vs), 1814 (sh), 1488 (m) $v(\mathrm{CO}) .{ }^{1} \mathrm{H} \mathrm{NMR}, 233 \mathrm{~K}, \mathrm{CDCl}_{3}: 6.17-5.06\left(\mathrm{~m}, 8 \mathrm{H}, \mathrm{C}_{5} \mathrm{H}_{4}\right)$; $3.38\left(\mathrm{~d}, \mathrm{~J} \mathrm{H-H}=3.4 \mathrm{~Hz}, 1 \mathrm{H}, \mathrm{CH}_{2}\right) ; 2.91(\mathrm{~d}, \mathrm{~J} \mathrm{H-H}=3.4 \mathrm{~Hz}, 1 \mathrm{H}$, $\left.\mathrm{CH}_{2}\right), 2.08,1.80(\mathrm{~s}, 6 \mathrm{H}, 2 \mathrm{Me}) .{ }^{13} \mathrm{C} \mathrm{NMR}, 233 \mathrm{~K}, \mathrm{CDCl}_{3}: 249.0$ $\left(\mathrm{CH}_{2} \mathrm{CO}\right.$ ); 242.7, 240.3 (t-CO); 228.5, 218.1 (t-CO); 119.3, 113.1 (2 MeC); 95.4-86.3 (8 CHs); 13.8, 13.3 (2 Me); -1.92 (J w-c = $\left.24.7 \mathrm{~Hz}, \mathrm{CH}_{2}\right)$. MS, FAB: $712\left(\mathrm{M}^{+}\right), 684\left(\mathrm{M}^{+}-\mathrm{CO}\right)$. Anal. Calcd for $\mathrm{C}_{19} \mathrm{H}_{16} \mathrm{O}_{6} \mathrm{~W}_{2}$ : C, 32.23; $\mathrm{H}, 2.28$. Found: C, 31.97; $\mathrm{H}, 2.11$.

NMR Monitoring of the Reaction of 1 with $\mathrm{CH}_{2} \mathrm{I}_{2}$ in $\mathrm{CD}_{3} \mathrm{CN}$ at $-25^{\circ} \mathbf{C}$. Complex 1 prepared in $0.50 \mathrm{~mL}$ of $\mathrm{CD}_{3} \mathrm{CN}$ from $13(0.11 \mathrm{~g}, 0.17 \mathrm{mmol})$ was delivered into an NMR tube, and $\mathrm{CH}_{2} \mathrm{I}_{2}(0.012 \mathrm{~mL}, 0.15 \mathrm{mmol})$ was added at $-25^{\circ} \mathrm{C}$. The NMR tube was quickly transferred into a precooled NMR probe $\left(-25^{\circ} \mathrm{C}\right)$, and the reaction was monitored by ${ }^{1} \mathrm{H} N M R$ spectroscopy. The three major products, $\mathbf{5}$ and two isomers of $\mathbf{6}$, were observed in the ${ }^{1} \mathrm{H}$ NMR spectrum. Spectroscopic data ( $\left.{ }^{1} \mathrm{H} \mathrm{NMR},-25^{\circ} \mathrm{C}, \mathrm{CD}_{3} \mathrm{CN}\right)$ are as follows. I somers of $\mathbf{6}$ : 5.56, (s, 5H, Cp); $4.87(\mathrm{~s}, 5 \mathrm{H}, \mathrm{Cp}) ; 2.23,2.08\left(\mathrm{AX}, \mathrm{J}_{\mathrm{H}-\mathrm{H}}=7.5\right.$ $\mathrm{Hz}, \mathrm{CH}_{2}$ ); 5.28, (s, 5H, Cp); 4.56 (s, 5H, Cp); 2.62, 2.24 (AX, $\left.\mathrm{J}_{\mathrm{H}-\mathrm{H}}=6.6 \mathrm{~Hz}, \mathrm{CH}_{2}\right)$. 5: 5.66, (s, 5H, Cp); $5.63(\mathrm{~s}, 5 \mathrm{H}, \mathrm{Cp})$; 3.52, $3.11\left(\mathrm{AX}, \mathrm{J}_{\mathrm{H}-\mathrm{H}}=3.7 \mathrm{~Hz}, \mathrm{CH}_{2}\right)$. The final products of this experiment are $\mathrm{Cp}(\mathrm{CO})_{3} \mathrm{WCH}_{3}$ and $\mathrm{Cp}(\mathrm{CO})_{3} \mathrm{WI}$, possibly due to the temperature fluctuation while the tube is transferred into and out of the NMR probe.

Reaction of $\mathbf{5}$ with $\mathbf{C O}$ in $\mathbf{C H}_{2} \mathbf{C l}_{2}$. Complex $\mathbf{5}(1.00 \mathrm{~g}$, $1.47 \mathrm{mmol}$ ) was dissolved in $15.0 \mathrm{~mL}$ of $\mathrm{CO}$-saturated $\mathrm{CH}_{2} \mathrm{Cl}_{2}$ in a Schlenk flask at $25^{\circ} \mathrm{C}$, and to prevent decomposition of $\mathbf{5}$ at this temperature, $\mathrm{CO}$ was immediately passed through the resulting solution. A slow reaction turned the color of the solution from red into yellowish-orange. After $45 \mathrm{~min}, 15 \mathrm{~mL}$ of cold hexane was added, and the solution was stored at -20 ${ }^{\circ} \mathrm{C}$ for $8 \mathrm{~h}$ to cause the first precipitation. The precipitate was collected by filtration and was identified as $\mathrm{Cp}(\mathrm{CO})_{3} \mathrm{WCH}_{2-}$ $\mathrm{COOH}(9)(0.09 \mathrm{~g}, 16 \%)$. Spectroscopic data of 9 are as follows. IR, $\mathrm{CH}_{2} \mathrm{Cl}_{2}$ : 2028 (m), 1924 (vs), 1600 (m) v(CO). ${ }^{1} \mathrm{H}$ NMR, $\mathrm{CDCl}_{3}$ : $5.52(\mathrm{~s}, 5 \mathrm{H}, \mathrm{Cp}) ; 2.04\left(\mathrm{~s}, \mathrm{CH}_{2}, \mathrm{~J} \mathrm{w}_{-\mathrm{H}}=5.6 \mathrm{~Hz}\right)$. MS, FAB: $394\left(\mathrm{M}^{+}\right), 366\left(\mathrm{M}^{+}-\mathrm{CO}\right), 338\left(\mathrm{M}^{+}-2 \mathrm{CO}\right)$. Anal. Calcd for $\mathrm{C}_{10} \mathrm{H}_{8} \mathrm{O}_{5} \mathrm{~W}$ : C, 30.64; $\mathrm{H}, 2.06$. Found: $\mathrm{C}, 30.45 ; \mathrm{H}, 1.87$. The filtrate was further cooled to $-20^{\circ} \mathrm{C}$ to cause the second precipitation. The solid was collected after filtration and washing with ether. The crude product was further purified by recrystallization from $\mathrm{CH}_{2} \mathrm{Cl}_{2}$ to give $\mathrm{Cp}_{2}(\mathrm{CO})_{6} \mathrm{~W}_{2}\left(\mu-\mathrm{CH}_{2} \mathrm{CO}\right)$ (8) $(0.57 \mathrm{~g})$ in $55 \%$ yield. Spectroscopic data of $\mathbf{8}$ are as follows. IR, $\mathrm{CH}_{2} \mathrm{Cl}_{2}$ : $2021(\mathrm{~m}), 2005(\mathrm{~m}), 1996(\mathrm{~m}), 1917(\mathrm{vs}), 1612(\mathrm{~m})$ $v(\mathrm{CO})$. ${ }^{1 \mathrm{H} ~ N M R}, \mathrm{CDCl}_{3}$ : 5.50 (s, 5H, Cp); 5.44 (s, 5H, Cp); $3.20\left(\mathrm{~s}, \mathrm{CH}_{2}, \mathrm{~J} \mathrm{w}-\mathrm{H}=4.6 \mathrm{~Hz}\right) .{ }^{13} \mathrm{C} \mathrm{NMR}, \mathrm{O}^{\circ} \mathrm{C}, \mathrm{CDCl}_{3}: 245.2$ (ketene CO); 228.9, 228.1, 221.0, 218.3 (CO); 94.8, 91.3 (2 Cps); $22.7\left(\mathrm{CH}_{2}\right)$. MS, FAB: $712\left(\mathrm{M}^{+}\right), 684\left(\mathrm{M}^{+}-\mathrm{CO}\right)$. Anal. Calcd for $\mathrm{C}_{18} \mathrm{H}_{12} \mathrm{O}_{7} W_{2}$ : C, 30.54; $\mathrm{H}, 1.71$. Found: $\mathrm{C}, 30.50 ; \mathrm{H}, 1.76$.

The complex $\mathrm{Cp}_{2}{ }_{2}(\mathrm{CO})_{6} \mathrm{~W}_{2}\left(\mu-\mathrm{CH}_{2} \mathrm{CO}\right)$ (8') was similarly prepared in $60 \%$ yield. Spectroscopic data of $\mathbf{8}$ are as follows. IR, $\mathrm{CH}_{2} \mathrm{Cl}_{2}$ : 2019 (s), 2004 (s), 1994 (sh), 1917 (vs), 1613 (m) $v(\mathrm{CO}) .{ }^{1} \mathrm{H} \mathrm{NMR}, \mathrm{CDCl}_{3}$ : $5.39-5.30\left(\mathrm{~m}, 8 \mathrm{H}, 2 \mathrm{C}_{5} \mathrm{H}_{4}\right) ; 3.15(\mathrm{~s}$, $\left.\mathrm{J} \mathrm{w}_{-\mathrm{H}}=5.1 \mathrm{~Hz}, 2 \mathrm{H}, \mathrm{CH}_{2}\right) ; 2.17(\mathrm{~s}, 3 \mathrm{H}, \mathrm{Me}) ; 2.13(\mathrm{~s}, 3 \mathrm{H}, \mathrm{Me})$. ${ }^{13} \mathrm{C} \mathrm{NMR},-30{ }^{\circ} \mathrm{C}, \mathrm{CDCl}_{3}$ : 247.5 (ketene $\mathrm{CO}$ ); 230.2, 229.6, 222.1, 219.6 (CO); 111.1, 109.0 (CMe); 95.8, 94.3, 92.2, 89.8 (8
$\mathrm{CH}) ; 24.1\left(\mathrm{CH}_{2}\right), 14.2,13.9(\mathrm{Me}) . \mathrm{MS}, \mathrm{FAB}: 740\left(\mathrm{M}^{+}\right), 712$ $\left(\mathrm{M}^{+}-\mathrm{CO}\right), 684\left(\mathrm{M}^{+}-2 \mathrm{CO}\right)$. Anal. Calcd for $\mathrm{C}_{20} \mathrm{H}_{16} \mathrm{O}_{7} \mathrm{~W}_{2}$ : C, 32.64; $\mathrm{H}, 2.19$. Found: $C, 32.58 ; \mathrm{H}, 2.25$.

Reaction of $\mathbf{5}$ with $\mathbf{P}(\mathrm{OMe})_{3}$ in $\mathbf{C H}_{\mathbf{2}} \mathbf{C l}_{\mathbf{2}}$. Complex $\mathbf{5}$ (1.45 $\mathrm{g}, 2.13 \mathrm{mmol}$ ) was dissolved in $40.0 \mathrm{~mL}$ of $\mathrm{CH}_{2} \mathrm{Cl}_{2}$ at $-20^{\circ} \mathrm{C}$, $\mathrm{P}(\mathrm{OMe})_{3}(0.312 \mathrm{~mL}, 2.65 \mathrm{mmol})$ was added via a syringe, and the resulting solution was stored at $-20{ }^{\circ} \mathrm{C}$ for 2 days. The solution turned from dark red into light yellow, and precipitates formed. The resulting mixture was filtered. The solid was collected after being washed with ether. The crude product was further purified by recrystallization from $\mathrm{CH}_{2} \mathrm{Cl}_{2}$ to give $\mathrm{Cp}_{2}(\mathrm{CO})_{5}\left[\mathrm{P}(\mathrm{OMe})_{3}\right] \mathrm{W}_{2}\left(\mu-\mathrm{CH}_{2} \mathrm{CO}\right)(\mathbf{1 0 a})(1.52 \mathrm{~g}, 1.90$ $\mathrm{mmol}$ ) in $89 \%$ yield. Spectroscopic data of $\mathbf{1 0 a}$ are as follows. IR, $\mathrm{CHCl}_{3}$ : 2038 (m), 2013 (m), 1999 (w), 1922 (vs), 1844 (s), $1601(\mathrm{~m}) v(\mathrm{CO}) .{ }^{1} \mathrm{H} \mathrm{NMR}, \mathrm{CDCl}_{3}: 5.44(\mathrm{~s}, 5 \mathrm{H}, \mathrm{Cp}) ; 5.28(\mathrm{~d}$, $\left.\mathrm{J}_{\mathrm{P}-\mathrm{H}}=1.3 \mathrm{~Hz}, 5 \mathrm{H}, \mathrm{Cp}\right) ; 3.62\left(\mathrm{~d}, \mathrm{~J} \mathrm{P}-\mathrm{H}=12.0 \mathrm{~Hz}, 9 \mathrm{H}, \mathrm{P}(\mathrm{OMe})_{3}\right)$; $3.22\left(\mathrm{~s}, 2 \mathrm{H}, \mathrm{CH}_{2}\right) .{ }^{13} \mathrm{C} \mathrm{NMR}, \mathrm{CDCl}_{3}: 250.9(\mathrm{~d}, \mathrm{~J} \mathrm{P}-\mathrm{C}=12.0 \mathrm{~Hz}$, CO); 230.1, 229.3 (d, J p-c = 27.2 Hz, CO); 218.3 (CO); 93.9, 90.9 (2 Cps); 52.7 (OMe); 23.6 (s, J w-c = 33.6, $23.0 \mathrm{~Hz}, \mathrm{CH}_{2}$ ). ${ }^{31} \mathrm{P} \mathrm{NMR}, \mathrm{CDCl}_{3}$ : $161.48(\mathrm{~s}, \mathrm{~J} \mathrm{p}-\mathrm{w}=389.7 \mathrm{~Hz})$. MS, FAB: 808 $\left(\mathrm{M}^{+}\right), 780\left(\mathrm{M}^{+}-\mathrm{CO}\right)$. Anal. Calcd for $\mathrm{C}_{20} \mathrm{H}_{21} \mathrm{O}_{9} \mathrm{~W}_{2} \mathrm{P}: \mathrm{C}, 29.87$; $H, 2.63$. Found: $C, 30.01 ; H, 2.77$.

$\mathrm{Cp}_{2}(\mathrm{CO})_{5}\left(\mathrm{PEt}_{3}\right) \mathrm{W}_{2}\left(\mu-\mathrm{CH}_{2} \mathrm{CO}\right)$ (10b) was similarly prepared in $85 \%$ yield. Spectroscopic data of $\mathbf{1 0 b}$ are as follows. IR, $\mathrm{CHCl}_{3}: 2011$ (m), 1998 (w), 1918 (vs), 1823 (s), 1595 (m) $v(\mathrm{CO})$. ${ }^{1} \mathrm{H} \mathrm{NMR}, \mathrm{CDCl}_{3}$ : 5.41 (s, 5H, Cp); $5.16\left(\mathrm{~d}, \mathrm{~J} \mathrm{P}_{-\mathrm{H}}=0.9 \mathrm{~Hz}, 5 \mathrm{H}\right.$, $\mathrm{Cp}) ; 3.22\left(\mathrm{~s}, 2 \mathrm{H}, \mathrm{CH}_{2}\right) ; 1.85,1.04\left(\mathrm{~m}, \mathrm{P}(\mathrm{Et})_{3}\right) .{ }^{13} \mathrm{C} \mathrm{NMR}$, $\mathrm{CDCl}_{3}$ : $252.8\left(\mathrm{~d}, \mathrm{~J}_{\mathrm{P}-\mathrm{C}}=9.5 \mathrm{~Hz}, \mathrm{CO}\right) ; 232.9\left(\mathrm{~d}, \mathrm{~J}_{\mathrm{P}-\mathrm{C}}=17.6\right.$ $\mathrm{Hz}, \mathrm{CO}$ ); 230.7, 218.4 (CO); 93.6, 91.0 (2 Cps); 24.8 (s, J w-c = 32.6, $22.9 \mathrm{~Hz}, \mathrm{CH}_{2}$ ); $22.6\left(\mathrm{~d}, \mathrm{~J} \mathrm{P}-\mathrm{C}=30.8 \mathrm{~Hz}^{\mathrm{P}} \mathrm{PCH}_{2}\right) ; 8.20(\mathrm{~d}$, $\left.\mathrm{J} \mathrm{P}-\mathrm{C}=2.2 \mathrm{~Hz}, \mathrm{CH}_{3}\right)$. ${ }^{31} \mathrm{P} \mathrm{NMR}, \mathrm{CDCl}_{3}: 15.10(\mathrm{~s}, \mathrm{~J} \mathrm{p}-\mathrm{w}=217.4$ $\mathrm{Hz})$. MS, FAB: $802\left(\mathrm{M}^{+}\right), 774\left(\mathrm{M}^{+}-\mathrm{CO}\right)$. Anal. Calcd for $\mathrm{C}_{23} \mathrm{H}_{27} \mathrm{O}_{6} \mathrm{PW}_{2}$ : C, 34.61; $\mathrm{H}, 3.41$; found: $\mathrm{C}, 34.77 ; \mathrm{H}, 3.27$.

$\mathrm{Cp}_{2}(\mathrm{CO})_{5}\left(\mathrm{PPh}_{3}\right) \mathrm{W}_{2}\left(\mu-\mathrm{CH}_{2} \mathrm{CO}\right)(\mathbf{1 0 c})$ was similarly prepared in $76 \%$ yield. Spectroscopic data of $\mathbf{1 0}$ are as follows. IR, KBr: 2004 (m), 1911 (vs), 1901 (vs), 1822 (s), 1591 (s) v(CO).

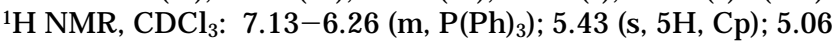
$(\mathrm{d}, \mathrm{J} \mathrm{P}-\mathrm{H}=1.1 \mathrm{~Hz}, 5 \mathrm{H}, \mathrm{Cp}) ; 3.32\left(\mathrm{CH}_{2}\right) .{ }^{13} \mathrm{C} \mathrm{NMR}, \mathrm{CDCl}_{3}: 252.2$ $\left(d, J_{P-C}=9.7 \mathrm{~Hz}, C O\right) ; 232.8\left(d, J_{P-C}=18.2 \mathrm{~Hz}, \mathrm{CO}\right) ; 230.4$, 218.6 (CO); 136-128 (m, Ph); 95.3, 91.0 (2 Cps); 24.3 (J w-c = 32.0, $22.0 \mathrm{~Hz}, \mathrm{CH}_{2}$ ). ${ }^{31} \mathrm{P} \mathrm{NMR}, \mathrm{CDCl}_{3}: 38.97(\mathrm{~s}, \mathrm{~J} \mathrm{P}-\mathrm{w}=231.4$ $\mathrm{Hz})$. MS, FAB: $946\left(\mathrm{M}^{+}\right), 918\left(\mathrm{M}^{+}-\mathrm{CO}\right)$. Anal. Calcd for $\mathrm{C}_{35} \mathrm{H}_{27} \mathrm{O}_{6} \mathrm{~W}_{2} \mathrm{P}: \mathrm{C}, 44.61 ; \mathrm{H}, 2.89$. Found: $\mathrm{C}, 44.53 ; \mathrm{H}, 2.92$.

Reaction of $\mathbf{5}$ with t-BuNC in $\mathbf{C H}_{3} \mathbf{C N}$. Complex $\mathbf{5}(0.50$ $\mathrm{g}, 0.74 \mathrm{mmol}$ ) was suspended in $10.0 \mathrm{~mL}$ of $\mathrm{CH}_{3} \mathrm{CN}$ at -20 ${ }^{\circ} \mathrm{C}$, t-BuNC (0.101 mL, $0.89 \mathrm{mmol}$ ) was added via a syringe, and the resulting solution was stored at $-20^{\circ} \mathrm{C}$ for 2 days. $\mathrm{A}$ slow reaction turned the dark red solid into a light yellow precipitate, and the resulting mixture was filtered. The sol id was collected after being washed with ether to give $\mathrm{Cp}_{2}(\mathrm{CO})_{5}(\mathrm{t}-$ BuNC)W $2\left(\mu-\mathrm{CH}_{2} \mathrm{CO}\right)(\mathbf{1 1})(0.52 \mathrm{~g})$ in $93 \%$ yield. This product contains cis and trans isomers of $\mathbf{1 1}$. Spectroscopic data of $\mathbf{1 1}$ are as follows. IR, $\mathrm{CH}_{2} \mathrm{Cl}_{4}: 2112(\mathrm{~m}) v(\mathrm{CN}) ; 2008(\mathrm{~m}), 1998$ (s), 1910 (vs), 1854 (s), 1589 (m) $v(\mathrm{CO}) .{ }^{1} \mathrm{H}$ NMR, $\mathrm{C}_{6} \mathrm{D}_{6}$ : trans isomer, $5.01(\mathrm{~s}, 5 \mathrm{H}, \mathrm{Cp}) ; 4.86(\mathrm{~s}, 5 \mathrm{H}, \mathrm{Cp}) ; 3.76\left(\mathrm{~s}, \mathrm{CH}_{2}\right) ; 0.92$ $\left(\mathrm{s}, 9 \mathrm{H}, \mathrm{CH}_{3}\right)$; cis isomer, $5.06(\mathrm{~s}, 5 \mathrm{H}, \mathrm{Cp}) ; 4.89(\mathrm{~s}, 5 \mathrm{H}, \mathrm{Cp}) ; 3.60$, $3.40\left(\mathrm{~J} \mathrm{H}-\mathrm{H}=13.5 \mathrm{~Hz}, \mathrm{CH}_{2}\right) ; 1.12\left(\mathrm{~s}, 9 \mathrm{H}, \mathrm{CH}_{3}\right) .{ }^{13} \mathrm{C} \mathrm{NMR}$, $\mathrm{CDCl}_{3}: 238.0,234.2,230.3,230.2,227.1,219.5,218.2,217.6$ (terminal CO); trans, $253.3\left(\mathrm{CH}_{2} \mathrm{CO}\right) ; 93.6,91.1$ (2 Cps); 59.2 $\left(\mathrm{CMe}_{3}\right) ; 31.0\left(\mathrm{Me}_{3}\right) ; 25.3\left(\mathrm{~s}, \mathrm{~J} w-\mathrm{c}=34.5 \mathrm{~Hz}, \mathrm{CH}_{2}\right) ; \mathrm{cis}, 255.4$ $\left(\mathrm{CH}_{2} \mathrm{CO}\right) ; 93.9,91.4(2 \mathrm{Cps}) ; 58.5\left(\mathrm{CMe}_{3}\right) ; 30.7\left(\mathrm{Me}_{3}\right) ; 23.6$ (s, $\left.\mathrm{J} w-\mathrm{C}=21.0 \mathrm{~Hz}, \mathrm{CH}_{2}\right)$. MS, FAB: $767\left(\mathrm{M}^{+}\right), 739\left(\mathrm{M}^{+}-\mathrm{CO}\right)$. The single crystals of the product were obtained by recrystallization from $\mathrm{CH}_{2} \mathrm{Cl}_{2}$ to give only the trans isomer for diffraction analysis and elemental analysis. Anal. Calcd for $\mathrm{C}_{22} \mathrm{H}_{21} \mathrm{O}_{6} \mathrm{NW}_{2}$ : C, 34.63; $\mathrm{H}, 2.77$. Found: C, 34.65; $\mathrm{H}, 2.56$.

Reaction of 8 with ROH. Complex $8(0.20 \mathrm{~g}, 0.28 \mathrm{mmol})$ was dissolved in $15.0 \mathrm{~mL}$ of $\mathrm{CH}_{2} \mathrm{Cl}_{2}$, and $\mathrm{PhCH}_{2} \mathrm{OH}(0.111 \mathrm{~mL}$, $1.02 \mathrm{mmol}$ ) was added. The resulting solution was stirred at room temperature for 2 days to give yellow precipitates. The solid was collected after being washed with ether, to give $\mathrm{Cp}(\mathrm{CO})_{3} \mathrm{WCH}_{2} \mathrm{COOCH}_{2} \mathrm{Ph}(\mathbf{1 2 c})(0.09 \mathrm{~g})$ in $65 \%$ yield. Two 
dinuclear complexes, 13 and $\left[\mathrm{Cp}(\mathrm{CO})_{2} \mathrm{~W}\right]_{2}$, were observed in the solution part as the byproducts. ${ }^{1} \mathrm{H} N M R$ for $\left[\mathrm{Cp}(\mathrm{CO})_{2} \mathrm{~W}\right]_{2}$ in $\mathrm{CDCl}_{3}$ : 5.36 . The crude product of $\mathbf{1 2 c}$ was further purified by recrystallization from $\mathrm{CH}_{2} \mathrm{Cl}_{2}$. Spectroscopic data of $\mathbf{1 2 C}$ are as follows. IR, $\mathrm{CH}_{2} \mathrm{Cl}_{2}$ : 2026 (m), 1923 (vs), 1679 (w) $v(\mathrm{CO}) .{ }^{1} \mathrm{H} N M R, \mathrm{CDCl}_{3}: 7.43-7.28(5 \mathrm{H}, \mathrm{Ph}) ; 5.34(\mathrm{~s}, 5 \mathrm{H}, \mathrm{Cp})$; $5.04\left(\mathrm{~s}, 2 \mathrm{H}, \mathrm{OCH}_{2}\right) ; 2.07\left(\mathrm{~s}, \mathrm{~J} \mathrm{w}-\mathrm{H}=5.5 \mathrm{~Hz} \mathrm{CH}_{2}\right) .{ }^{13} \mathrm{C} \mathrm{NMR}$ $\mathrm{CDCl}_{3}$ : 228.2, 216.2 (CO); 181.7 (COO); 136.8, 128.9, 128.4, $128.0(\mathrm{Ph}) ; 91.8(\mathrm{Cp}) ; 65.5\left(\mathrm{CH}_{2}\right) ;-15.2\left(\mathrm{CH}_{2}, \mathrm{~J} \mathrm{w}-\mathrm{C}=34.9 \mathrm{~Hz}\right)$. MS, FAB: $482\left(\mathrm{M}^{+}\right), 454\left(\mathrm{M}^{+}-\mathrm{CO}\right), 426\left(\mathrm{M}^{+}-2 \mathrm{CO}\right)$. Anal. Calcd for $\mathrm{C}_{17} \mathrm{H}_{14} \mathrm{O}_{5} \mathrm{~W}$ : C, 42.35; $\mathrm{H}, 2.93$. Found: $\mathrm{C}, 42.30 ; \mathrm{H}$, 2.90. Complexes $\mathrm{Cp}(\mathrm{CO})_{3} \mathrm{WCH}_{2} \mathrm{COOCH}_{3}$ (12a) and $\mathrm{Cp}(\mathrm{CO})_{3^{-}}$ $\mathrm{WCH}_{2} \mathrm{COOC}_{2} \mathrm{H}_{5}$ (12b) were similarly prepared in $50 \%$ and $48 \%$ yields, respectively. Spectroscopic data of $\mathbf{1 2 a}$ are as follows. IR, $\mathrm{CH}_{2} \mathrm{Cl}_{2}$ : 2026 (m), 1920 (vs), 1682 (w) $v(\mathrm{CO}) .{ }^{1} \mathrm{H}$ NMR, $\mathrm{CDCl}_{3}$ : $5.49(\mathrm{~s}, 5 \mathrm{H}, \mathrm{Cp}) ; 3.58(\mathrm{~s}, 3 \mathrm{H}, \mathrm{OMe}) ; 2.03\left(\mathrm{~s}, \mathrm{~J} \mathrm{w}_{-\mathrm{H}}=\right.$ $5.6 \mathrm{~Hz} \mathrm{CH}_{2}$ ). ${ }^{13} \mathrm{C} \mathrm{NMR,} \mathrm{CDCl}_{3}$ : 216.2, 202.7 (CO); 182.6 (COO); $91.9(\mathrm{Cp}) ; 50.7$ (OMe); $-15.4\left(\mathrm{CH}_{2}\right)$. MS, FAB: 408 $\left(\mathrm{M}^{+}\right), 380\left(\mathrm{M}^{+}-\mathrm{CO}\right), 352\left(\mathrm{M}^{+}-2 \mathrm{CO}\right)$. Anal. Calcd for $\mathrm{C}_{11} \mathrm{H}_{10} \mathrm{O}_{5} \mathrm{~W}$ : C, 32.53; $\mathrm{H}, 2.48$. Found: C, 32.73; $\mathrm{H}, 2.54$. Spectroscopic data of $\mathbf{1 2} \mathbf{b}$ are as follows. ${ }^{1} \mathrm{H} \mathrm{NMR,} \mathrm{CDCl}_{3}$ : 5.49 (s, 5H, Cp); 4.02 (q, J $\mathrm{H}-\mathrm{H}=7.2 \mathrm{~Hz}, 2 \mathrm{H}, \mathrm{OCH}_{2}$ ); 2.01 (s, $\left.\mathrm{J} w-\mathrm{H}=5.2 \mathrm{~Hz}, \mathrm{CH}_{2}\right) 1.22(\mathrm{t}, \mathrm{J} \mathrm{H}-\mathrm{H}=7.2 \mathrm{~Hz}, 3 \mathrm{H}, \mathrm{Me})$. MS, FAB: $422\left(\mathrm{M}^{+}\right), 394\left(\mathrm{M}^{+}-\mathrm{CO}\right), 366\left(\mathrm{M}^{+}-2 \mathrm{CO}\right), 338\left(\mathrm{M}^{+}-\right.$ 3CO).

Reaction of $\mathbf{8}$ with i-PrNH2. Reaction of complex $\mathbf{8}(0.20$ $\mathrm{g}, 0.28 \mathrm{mmol}$ ) with i-PrNH $\mathrm{H}_{2}$ was similarly carried out in 10.0 $\mathrm{mL}$ of $\mathrm{CH}_{2} \mathrm{Cl}_{2}$. The workup was the same as that used in the reaction of $\mathrm{PhCH}_{2} \mathrm{OH}$. Crude product was purified by recrystallization from $\mathrm{CH}_{2} \mathrm{Cl}_{2}$ to give $\mathrm{Cp}(\mathrm{CO})_{3} \mathrm{WCH}_{2} \mathrm{CONH}$ (i-Pr) (14) $(0.10 \mathrm{~g})$ in $77 \%$ yield. Spectroscopic data of $\mathbf{1 4}$ are as follows. $\mathrm{IR}, \mathrm{CH}_{2} \mathrm{Cl}_{2}$ : 2019 (m), 1911 (vs), 1622 (w) $v(\mathrm{CO}) .{ }^{1} \mathrm{H} \mathrm{NMR}$, $\mathrm{CDCl}_{3}$ : $5.58(\mathrm{~s}, 5 \mathrm{H}, \mathrm{Cp}) ; 5.12(\mathrm{br}, 1 \mathrm{H}, \mathrm{NH}) ; 3.96(\mathrm{~m}, \mathrm{H}, \mathrm{CH})$; $1.97\left(\mathrm{~s}, 2 \mathrm{H}, \mathrm{CH}_{2}\right), 1.10(\mathrm{~d}, \mathrm{~J} \mathrm{H}-\mathrm{H}=6.6 \mathrm{~Hz}, 6 \mathrm{H}, 2 \mathrm{Me}) .{ }^{13} \mathrm{C} \mathrm{NMR}$, $\mathrm{CDCl}_{3}$ : 227.9, $217.8(\mathrm{CO}) ; 180.0(\mathrm{CON}) ; 92.1(\mathrm{Cp}) ; 41.3(\mathrm{CH})$; $22.9(\mathrm{Me}) ;-10.9\left(\mathrm{CH}_{2}\right)$. MS, FAB: $435\left(\mathrm{M}^{+}\right), 407\left(\mathrm{M}^{+}-\mathrm{CO}\right)$, $379\left(\mathrm{M}^{+}-2 \mathrm{CO}\right), 342\left(\mathrm{M}^{+}-\mathrm{CH}_{2} \mathrm{CONH}(\mathrm{i}-\mathrm{Pr})\right)$. Anal. Calcd for $\mathrm{C}_{13} \mathrm{H}_{15} \mathrm{O}_{4} W N$ : C, 36.05; $\mathrm{H}, 3.49$. Found: $\mathrm{C}, 36.27 ; \mathrm{H}, 3.59$. Two dinudear complexes, $\left[\mathrm{Cp}(\mathrm{CO})_{3} \mathrm{~W}\right]_{2}$ and $\left[\mathrm{Cp}(\mathrm{CO})_{2} \mathrm{~W}\right]_{2}$, were also observed as products.

Thermolysis of 10a. Complex $10 \mathrm{a}(0.14 \mathrm{~g}, 0.17 \mathrm{mmol})$ was dissolved in $15 \mathrm{~mL}$ of $\mathrm{CHCl}_{3}$, and the solution was heated to reflux for $8 \mathrm{~h}$. The IR spectrum indicated complete consumption of the starting material. The solvent was removed under vacuum, and the residue was extracted with $2 \times 20 \mathrm{~mL}$ of 1:1 hexane/ $\mathrm{CH}_{2} \mathrm{Cl}_{2}$. After removal of the solvent, the product was washed with $5 \times 10 \mathrm{~mL}$ of hexane to remove $\mathrm{Cp}(\mathrm{CO})_{3} \mathrm{WCl}$, and then the residue was recrystallized from 1:1 hexane/ $\mathrm{CH}_{2} \mathrm{Cl}_{2}$ to give $\mathrm{Cp}(\mathrm{CO})_{2}\left[\mathrm{P}(\mathrm{OMe})_{3}\right]$ WCOMe (16) $(0.06 \mathrm{~g}, 0.13$ $\mathrm{mmol}, \mathbf{7 5} \%$ yield). Spectroscopic data of $\mathbf{1 6}$ are as follows. IR, $\mathrm{CH}_{2} \mathrm{Cl}_{2}$ : 1957 (vs), 1851 (s) $v(\mathrm{CO}) .{ }^{1} \mathrm{H} \mathrm{NMR}, \mathrm{CDCl}_{3}: 5.30$ (d, $\left.\mathrm{J}_{\mathrm{P}-\mathrm{H}}=1.1 \mathrm{~Hz}, 5 \mathrm{H}, \mathrm{Cp}\right)$; $3.64\left(\mathrm{~d}, \mathrm{~J}_{\mathrm{P}-\mathrm{H}}=11.8 \mathrm{~Hz}, 9 \mathrm{H}, \mathrm{OMe}\right)$; $2.56(\mathrm{~s}, 3 \mathrm{H}, \mathrm{Me}) .{ }^{13} \mathrm{C} \mathrm{NMR}, \mathrm{CDCl}_{3}: 251.4(\mathrm{~d}, \mathrm{~J} \mathrm{p}-\mathrm{C}=13.0 \mathrm{~Hz}$, $\mathrm{C}=0$ ); 231.2 (d, J p-C $=17.4 \mathrm{~Hz}, \mathrm{CO}) ; 93.1$ (Cp); 58.1 (Me); 53.2 (OMe). ${ }^{31} \mathrm{P} \mathrm{NMR}, \mathrm{CDCl}_{3}: 160.0(\mathrm{~J} \mathrm{P}-\mathrm{W}=372.4 \mathrm{~Hz})$. MS, FAB: $474\left(\mathrm{M}^{+}\right), 459\left(\mathrm{M}^{+}-\mathrm{Me}\right), 446\left(\mathrm{M}^{+}-\mathrm{CO}\right), 431\left(\mathrm{M}^{+}-\right.$ COMe), $418\left(\mathrm{M}^{+}-2 \mathrm{CO}\right)$. Anal. Calcd for $\mathrm{C}_{12} \mathrm{H}_{17} \mathrm{O}_{6} \mathrm{WP}$ : C, 30.54; $H$, 3.63. Found: C, 30.35; $H, 3.70$.

Single-Crystal X-ray Analysis. Dark red single crystals of $\mathbf{Z}$ suitable for $\mathrm{X}$-ray diffraction study were grown directly from the reaction mixture of $\mathbf{1}^{\prime}$ with $\mathrm{CH}_{2} \mathrm{I}_{2}$ in $\mathrm{CH}_{3} \mathrm{CN}$. A suitable single crystal of dimensions $0.25 \times 0.35 \times 0.50 \mathrm{~mm}^{3}$ was glued to a glass fiber and mounted on an Enraf-Nonius CAD4 diffractometer. I nitial lattice parameters were determined from a least-squares fit to 25 accurately centered reflections $19.18^{\circ}<2 \theta<31.08^{\circ}$ and subsequently refined using higher angle data. Cell constants and other pertinent data are collected in Table I (in Supporting I nformation). Data were collected using the $\theta-2 \theta$ scan method. The final scan speed for each reflection was determined from the net intensity gathered during an initial prescan and ranged from 2.75 to $8.24 \mathrm{deg} / \mathrm{min}$. The scan angle was determined for each reflection according to the expression $0.85+0.35 \tan \theta$. Three check reflections were measured every $60 \mathrm{~min}$ throughout the data collection period and showed no apparent decay.

The raw intensity data were converted to structure factor amplitudes and their esd's by correction for scan speed, background, and Lorentz and polarization effects. An empirical correction for absorption $\left(\mu=119.17 \mathrm{~cm}^{-1}\right)$, based on the azimuthal scan data, was applied to the intensities. Crystallographic computations were carried out on a Microvax III computer using the NRCC structure determination package. Merging of equivalent and duplicate reflections gave a total of 1733 unique measured data, of which 1433 were considered observed, I > 2.0 $\sigma(\mathrm{I})$. The structure was first solved by using the heavy-atom method (Patterson synthesis), which revealed the position of metal, and then refined via standard leastsquares and difference Fourier techniques. The quantity minimized by the least-squares program was $w\left(\left|F_{o}\right|-\left|F_{c}\right|\right)^{2}$, where $w$ is the weight of a given operation. The analytical forms of the scattering factor tables for the neutral atoms were used. ${ }^{31}$ All other non-hydrogen atoms were refined by using anisotropic thermal parameters. Hydrogen atoms were included in the structure factor calculations in their expected positions on the basis of idealized bonding geometry but were not refined in least squares. Final refinement using fullmatrix least squares converged smoothly to values of $R=0.034$ and $R_{w}=0.035$. Final values of all refined atomic positional parameters (with esd's) and tables of thermal parameters are given in the Supporting Information.

The procedures for the structure determination of $\mathbf{5}^{\prime}, \mathbf{8}$, and $\mathbf{1 1}$ are similar. The final residuals of the refinement are $\mathrm{R}$, $\mathrm{R}_{\mathrm{w}}=0.031,0.032 ; 0.032,0.032$; and $0.057,0.065$ for $\mathbf{5}^{\prime}, \mathbf{8}$, and $\mathbf{1 1}$, respectively. Final values of all refined atomic positional parameters (with esd's), thermal parameters, and bond distances and angles are given in the Supporting Information.

Acknowledgment. We are grateful for support of this work by National Science Council, Republic of China.

Supporting Information Available: Tables of the structural determination for complexes $\mathbf{2}, \mathbf{5}^{\prime}, \mathbf{8}$, and $\mathbf{1 1}$ including data collection, positional and anisotropic thermal parameters, and bond distances and angles (12 pages). Ordering information is given on any current masthead page.

\section{OM 9609980}

(31) International Tables for X-ray Crystallography; D. D. Reidel Pub. Co.: Dordrecht, Boston, 1974; Vol. IV. 